\title{
Discovery and Preclinical Characterization of GSK1278863 (Daprodustat), a Small Molecule Hypoxia Inducible Factor-Prolyl Hydroxylase Inhibitor for Anemia ${ }^{[\mathbf{s}}$
}

\author{
Jennifer L. Ariazi, Kevin J. Duffy, David F. Adams, Duke M. Fitch, Lusong Luo, \\ Melissa Pappalardi, Mangatt Biju, Erin Hugger DiFilippo, Tony Shaw, Ken Wiggall, \\ and Connie Erickson-Miller
}

\begin{abstract}
GlaxoSmithKline, King of Prussia, Pennsylvania (JLA, DFA, DF, TS, KJD, MP, MB, KW) and while at GlaxoSmithKline, King of
\end{abstract} Prussia, Pennsylvania (LL, EHDF, CE-M)

Received April 28, 2017; accepted July 26, 2017

\begin{abstract}
Decreased erythropoietin (EPO) production, shortened erythrocyte survival, and other factors reducing the response to EPO contribute to anemia in patients who have a variety of underlying pathologies such as chronic kidney disease. Treatment with recombinant human EPO (rHuEPO) at supraphysiologic concentrations has proven to be efficacious. However, it does not ameliorate the condition in all patients, and it presents its own risks, including cardiovascular complications. The transcription factors hypoxia-inducible factor (HIF) $1 \alpha$ and HIF2 $\alpha$ control the physiologic response to hypoxia and invoke a program of increased erythropoiesis. Levels of $\mathrm{HIF} \alpha$ are modulated by oxygen tension via the action of a family of HIF-prolyl hydroxylases (PHDs), which tag HIF $\alpha$ for proteasomal degradation. Inhibition of these PHDs simulates conditions of mild hypoxia, leading to a potentially more physiologic erythropoietic response
\end{abstract}

and presenting a potential alternative to high doses of rHuEPO. Here we describe the discovery and characterization of GSK1278863 [2-(1,3-dicyclohexyl-6-hydroxy-2,4-dioxo-1,2,3,4tetrahydropyrimidine-5-carboxamido) acetic acid], a pyrimidinetrioneglycinamide low nanomolar inhibitor of PHDs 1-3 that stabilizes $\mathrm{HIF} \alpha$ in cell lines, resulting in the production of increased levels of EPO. In normal mice, a single dose of GSK1278863 induced significant increases in circulating plasma EPO but only minimal increases in plasma vascular endothelial growth factor (VEGF-A) concentrations. GSK1278863 significantly increased reticulocytes and red cell mass parameters in preclinical species after once-daily oral administration and has demonstrated an acceptable nonclinical toxicity profile, supporting continued clinical development. GSK1278863 is currently in phase 3 clinical trials for treatment of anemia in patients with chronic kidney disease.

\section{Introduction}

Since its discovery as the hypoxia-induced complex responsible for erythropoietin (EPO) transcriptional regulation (Pugh et al., 1991; Semenza et al., 1991; Semenza and Wang, 1992), hypoxiainducible factor (HIF) has been shown to recognize hypoxiaresponse elements in many diverse genes (Schodel et al., 2011; Semenza, 2012). The HIF family includes three hypoxiaresponsive proteins: HIF $1 \alpha$ (Wang et al., 1995), HIF2 $\alpha$ (Tian et al., 1997), and HIF3 $\alpha$ (Makino et al., 2001). HIF $\alpha$ proteins form a heterodimer with HIF $\beta$ (Hoffman et al., 1991), resulting in a transcriptionally active DNA binding complex. There is a large diversity of genes regulated by $\mathrm{HIF} \alpha$, (Schodel et al., 2011)

This work was supported by GlaxoSmithKline.

https://doi.org/10.1124/jpet.117.242503.

S This article has supplemental material available at jpet.aspetjournals.org. with some cell-type and environment specificity in gene regulation (Ratcliffe, 2007; Loboda et al., 2010, 2012; Mathieu et al., 2014). Dysregulation of HIF is associated with several pathologies, including cardiac failure (Wei et al., 2012; Bishop and Ratcliffe, 2015), stroke (Philipp et al., 2006; Bao et al., 2010), lung disease (Whyte and Walmsley, 2014), and retinal damage (Semenza et al., 2000; Arjamaa and Nikinmaa, 2006).

Under normoxia, $\mathrm{HIF} \alpha$ is continually ubiquitinated and degraded by the proteasome (Fig. 1). E3 ubiquitin ligasemediated degradation of $\mathrm{HIF} \alpha$ depends upon interaction with von Hippel-Lindau tumor suppressor protein (Maxwell et al., 1999; Cockman et al., 2000). The oxygen-sensing mechanism controlling HIF $\alpha$ stabilization involves a family of HIF-prolyl hydroxylases (PHDs) (Epstein et al., 2001), which regulate the hydroxylation of conserved proline residues in $\mathrm{HIF} \alpha$, furnishing the essential recognition element for the HIF $\alpha$-VHL interaction (Ivan et al., 2001; Jaakkola et al., 2001). The PHDs

\footnotetext{
ABBREVIATIONS: BSA, bovine serum albumin; CHAPS, 3-[(3-cholamidopropyl)dimethylammonio]-1-propanesulfonate; CODDD, C-terminal oxygen-dependent degradation domain; $\mathrm{CP} 4 \mathrm{H}$, collagen prolyl hydroxylase; DFX, deferoxamine; DMSO, dimethylsulfoxide; ELISA, enzyme-linked immunosorbent assay; EPO, erythropoietin; Eu, Europium; FIH, factor-inhibiting HIF; FLIPR, fluorimetric imaging plate reader; FRET, fluorescence resonance energy transfer; GSK1278863, 2-[(1,3-dicyclohexyl-2,4,6-trioxo-1,3-diazinane-5-carbonyl)amino]acetic acid (daprodustat); HIF, hypoxiainducible factor; $5 \mathrm{HT}$, 5-hydroxytryptamine; $\alpha$-KG, $\alpha$-ketoglutarate; PHD, hypoxia-inducible factor prolyl hydroxylase; PPP, platelet-poor plasma; rHuEPO, recombinant human erythropoietin; TBST, Tris-buffered saline containing $0.1 \%$ Tween-20; TCEP, tris(2-carboxyethyl)phosphine hydrochloride; VBC, von Hippel-Lindau protein-elongin B-elongin C; VEGF, vascular endothelial growth factor.
} 


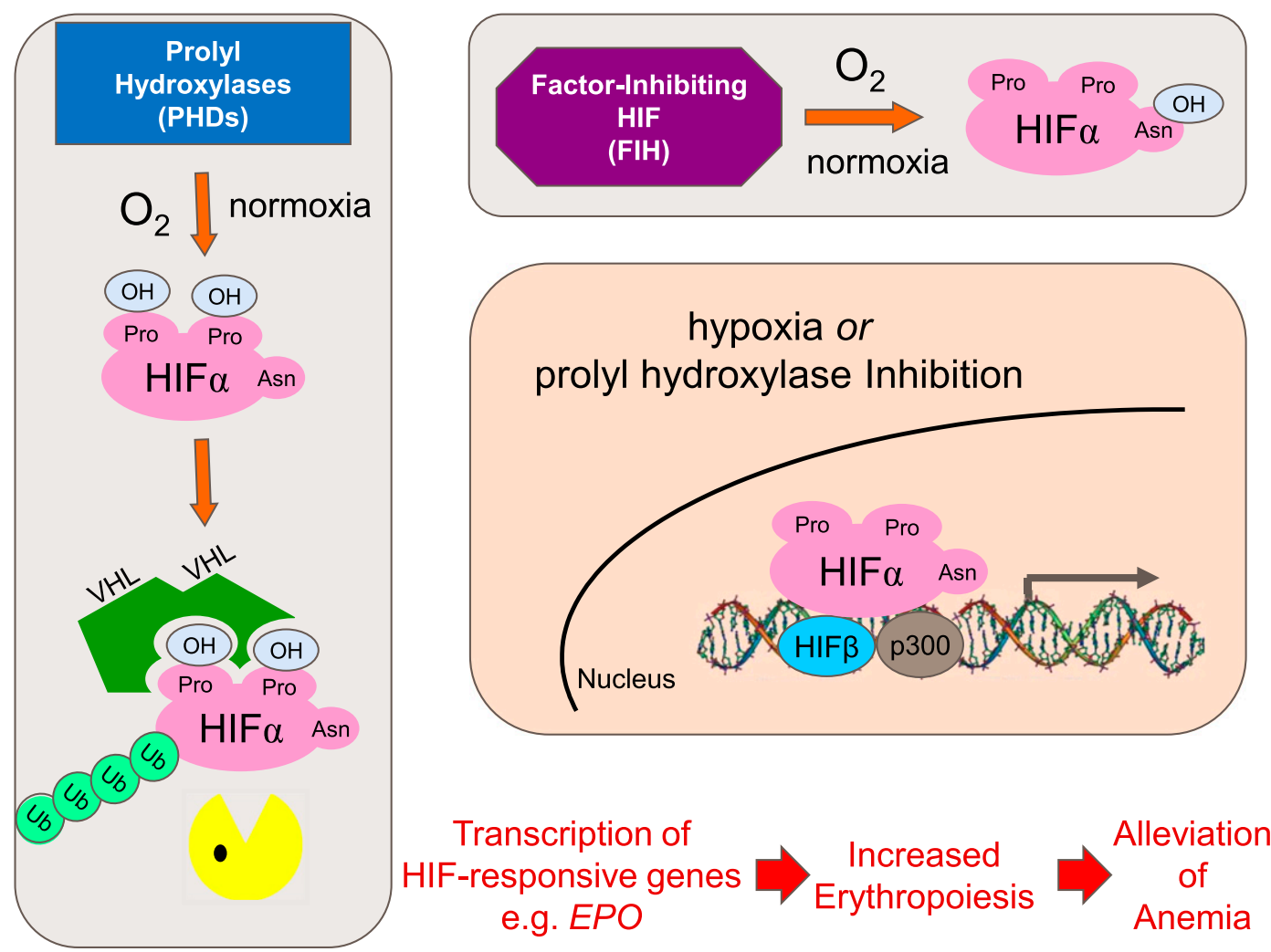

Fig. 1. Schematic diagrams of the oxygen-dependent, transcriptional regulation by HIF $\alpha$. Under normoxia, prolyl hydroxylases use oxygen to hydroxylate proline residues on $\mathrm{HIF} \alpha$, enabling its VHL-mediated degradation via proteasomes (ub refers to ubiquitin). FIH hydroxylates an asparagine residue on $\mathrm{HIF} \alpha$, preventing it from binding its transcriptional coactivator p300. However, under increasing levels of hypoxia, first prolyl hydroxylase activity, then FIH activity is diminished, resulting in accumulation of HIF $\alpha$ and interaction with p300, leading to transcription of HIF-responsive genes, including those responsible for up-regulation of erythropoiesis.

are members of the iron and $\alpha$-ketoglutarate $(\alpha$-KG)dependent dioxygenase superfamily and are found in overlapping but distinct tissue expression patterns (Lieb et al., 2002) with differences in subcellular localization.

The functional differences between the PHD isoforms are not well understood, but mouse genetic knockout studies suggest they have distinct functions and phenotypes (Minamishima et al., 2008; Takeda et al., 2008). In humans, a loss of function mutation in PHD2 was associated with familial erythrocytosis (Percy et al., 2006). PHD2 was found to be the primary regulator of HIF- $1 \alpha$ levels in normoxia (Berra et al., 2003), while PHD3 was found to be the primary regulator of $\mathrm{HIF} 2 \alpha$, especially where $\mathrm{PHD} 3$ expression exceeded that of PHD2 under conditions of hypoxia (Appelhoff et al., 2004). Because the relative amounts of PHDs in EPO-producing cells in vivo are unknown, particularly in anemia, it is not clear which PHD or combination of PHDs should be inhibited to produce the best EPO-producing physiologic response. To date, no isoform-selective, 2-KGcompetitive PHD inhibitors have been reported.

HIF activity is further regulated by factor-inhibiting HIF (FIH) (Mahon et al., 2001; Hewitson et al., 2002; Lando et al., 2002). FIH hydroxylates $\mathrm{HIF} \alpha$ on an asparagine in the C-terminal transactivation domain (C-TAD), inhibiting the binding of $\mathrm{HIF} \alpha$ to its transcriptional coactivator, p300. FIH activity is prevalent under oxygen conditions lower than those where PHDs are active; investigation of the interplay of these systems in regulation of the hypoxic response is ongoing (Chan et al., 2016).
Inhibition of PHDs results in HIF stabilization and modulation of HIF-controlled gene products, including EPO. Therefore, approaches that target HIF stabilization through PHD inhibition and the production of physiologic levels of endogenous EPO could alleviate anemia through increased reticulocyte production and subsequently increase erythrocyte levels, leading to increased hemoglobin and hematocrit levels and improved oxygen delivery (Forristal and Levesque, 2014). Furthermore, HIF affects iron metabolism modulators, including hepcidin (Yoon et al., 2006). A hepcidin decrease through PHD inhibition and hematopoiesis (Liu et al., 2012) may increase bioavailability of oral iron through increased absorption from the gut and allow better mobilization of iron stores from the liver and macrophages, potentially reducing or eliminating the need for iron supplementation often required for patients receiving recombinant human erythropoietin (rHuEPO).

Herein, we describe the discovery and preclinical development of GSK1278863 [2-(1,3-dicyclohexyl-6-hydroxy2,4-dioxo-1,2,3,4-tetrahydropyrimidine-5-carboxamido) acetic acid], a potent PHD inhibitor that mimics the binding of $\mathrm{N}$-oxalylglycine, involving chelation of the catalytic iron and blocking substrate entry. We describe how enzymatic inhibition of PHD2 and PHD3 results in stabilization of cellular HIF $1 \alpha$ and HIF $2 \alpha$, leading to production of EPO and subsequent induction of erythropoiesis in vivo in preclinical species. We also demonstrate selectivity of GSK1278863 against the related enzymes collagen prolyl hydroxylase $(\mathrm{CP} 4 \mathrm{H})$ and $\mathrm{FIH}$, and we describe an association established 
in nonclinical studies of structurally similar compounds between off-target activity on $\mathrm{CP} 4 \mathrm{H}$ and development of cardiac valve lesions.

\section{Materials and Methods}

GSK1278863 was synthesized as previously described elsewhere (Duffy et al., 2007). All studies used the free acid form of the compound, GSK1278863A.

All studies were conducted in accordance with the GlaxoSmithKline Policy on the Care, Welfare and Treatment of Laboratory Animals and were reviewed by the Institutional Animal Care and Use Committee either at GlaxoSmithKline or by the ethical review process at the institution where the work was performed.

\section{Western Blots for HIF Stabilization}

The human hepatocellular carcinoma Hep3B cell line obtained from American Type Culture Collection (ATCC, Manassas, VA) was maintained in log phase growth by routine subcultivation in high glucose/glutamine Dulbecco's modified Eagle medium containing 10\% fetal bovine serum under standard culture conditions $\left(37^{\circ} \mathrm{C}, 5 \% \mathrm{CO}_{2}\right)$.

We plated $2 \times 10^{6}$ Hep3B cells into P-100 cell culture dishes. After 48 hours, the dishes were treated with $100 \mu \mathrm{M}$ deferoxamine (DFX, positive control), or 25 or $50 \mu \mathrm{M}$ GSK1278863 in fresh medium. Dishes treated with dimethylsulfoxide (DMSO) $(0.1 \%)$ were used as negative controls. The dishes were incubated for 6 hours in a $\mathrm{CO}_{2}$ incubator at $37^{\circ} \mathrm{C}$. Nuclear extract was prepared using the Nuclear Extract Kit (Active Motif, Carlsbad, CA) according to the manufacturer's instructions. Protein concentrations were determined using Bio-Rad protein assay reagent (Bradford method; Bio-Rad Laboratories, Hercules, CA) with bovine serum albumin (BSA) at standard concentrations.

Protein samples were denatured at $99^{\circ} \mathrm{C}$ for 10 minutes in Laemmli sample buffer, resolved on a $7 \%$ Tris-acetate gel, and transferred to a nitrocellulose membrane. The blot was stained with Ponceau $\mathrm{S}$ to ensure equal loading. The membrane was washed and blocked with $10 \%$ Carnation milk (Nestlé USA, Rosslyn, VA) in Tris-buffered saline containing $0.1 \%$ Tween 20 (TBST) at room temperature for 20 minutes. The membrane was then incubated overnight at $4^{\circ} \mathrm{C}$ on a rocking platform with mouse monoclonal HIF-1 $\alpha$ (NB100-105; 1:350; Novus Biologicals, Oakville, ON, Canada) or rabbit polyclonal HIF- $2 \alpha$ (NB100-122: 1:1000; Novus Biologicals) antibodies diluted in 5\% milk TBST. Blots were washed in TBST 5 times and incubated for 1 hour with donkey anti-rabbit IgG (NA934; 1:2000; GE Healthcare, Piscataway, NJ) or sheep anti-mouse IgG (NA931; 1:2000; GE Healthcare) conjugated to horseradish peroxidase. Antibody-protein complexes were then detected using ECL-Plus (GE Healthcare) according to the manufacturer's instructions.

\section{Enzyme Assays}

Materials. LANCE Eu-W8044 streptavidin and $\alpha$-[1-14C]ketoglutaric acid were both purchased from PerkinElmer (Waltham, MA). HIF1 $\alpha$ CAD peptide (D788-L822) was purchased from 21st Century Biochemicals (Marlborough, MA). Dansyl-GFPG-Oet and (PP-G)10 peptides were purchased from California Peptide Research (Napa, CA). All other chemicals and materials were of standard laboratory grade.

The following recombinant proteins were used for the biochemical assays: his-strep-tev-PHD2 (1-426), his-strep-tev-PHD1 (1-407), hisMBP-att-PHD3 (1-239), his-MBP-tev-FIH (1-349), Cy5-his-gb1-tevHIF $2 \alpha$ C-terminal oxygen-dependent degradation domain (CODDD) (467-572), Cy5-his-gb1-tev-HIF1 $\alpha$ CODDD (498-603), and biotinVBC complex (composed of biotin-VHL, elongin b, and elongin c). Detailed protein expression and purification information can be found in the report by Pappalardi et al. (2008, 2011). Expression and purification of $\mathrm{CP} 4 \mathrm{H}$ were based on the methods described by Kersteen et al. (2004) except a baculovirus infected insect cell (BIIC) expression system was used. The $\mathrm{CP} 4 \mathrm{H}$ protein used for the biochemical assays was a tetramer comprised of full-length human collagen prolyl hydroxylase subunits A (P4HA) and B (P4HB).

LANCE Assay. Human PHD3 in vitro enzymatic activity was measured using a LANCE (homogeneous time-resolved fluorescence quenching assay based on lanthanide chelates) format. When hydroxylated, Cy5-HIF- $2 \alpha$ CODDD was recognized by the biotin-labeled von Hippel-Lindau protein-Elongin B-Elongin C (VBC) complex. The addition of europium $(\mathrm{Eu})$-streptavidin allowed detection of product formation by fluorescence resonance energy transfer, with a ratio of Cy5 to Eu fluorescence emission (LANCE ratio) as the ultimate readout. Assays were performed at room temperature using a $10 \mu \mathrm{l}$ reaction volume in black 384-well Nunc nonbinding assay plates prestamped with $100 \mathrm{nl}$ of compound in $100 \%$ DMSO.

The reactions were performed by dispensing enzyme ( $5 \mu \mathrm{l}$ of PHD3; prepared as a $2 \times$ concentrate containing $4.0 \mathrm{nM}$ PHD3, $0.2 \mathrm{mg} / \mathrm{ml}$ BSA, $400 \mu \mathrm{M}$ ascorbic acid, $1.25 \mu \mathrm{g} / \mathrm{ml} \mathrm{FeCl} 2,0.3 \mathrm{mM} \mathrm{3-[(3-}$ cholamidopropyl)dimethylammonio]-1-propanesulfonate [CHAPS], and $50 \mathrm{mM} \mathrm{KCl}$ in $50 \mathrm{mM}$ HEPES at $\mathrm{pH}$ 7.5) into the assay plates, incubating the plates for 30 minutes, and then adding the substrate (5 $\mu$ l HIF $2 \alpha$-CODDD; $2 \times$ concentrate contained $50 \mathrm{nM}$ Cy5-labeled HIF $2 \alpha$-CODDD, $25 \mathrm{nM}$ biotin-VBC, $1 \mu \mathrm{g} / \mathrm{ml}$ streptavidin-Eu, $20 \mu \mathrm{M}$ $\alpha$-ketoglutarate, $0.3 \mathrm{mM}$ CHAPS, and $50 \mathrm{mM} \mathrm{KCl}$ in $50 \mathrm{mM}$ HEPES at $\mathrm{pH}$ 7.5).

The reactions were incubated for 30 minutes and then read on a PerkinElmer Viewlux imager at an excitation wavelength of $360 \mathrm{nM}$ and emission wavelengths of 610 and $660 \mathrm{nM}$. The raw data values are the quotient of the signal intensities at 660 and 610 (LANCE ratio), and inhibition in each assay well was calculated as a proportion of the high and low control wells. The final concentration of $\alpha$-ketoglutarate in the assay was set to be equivalent to $\sim 2 \times K_{\mathrm{m}}^{\mathrm{app}}$.

The human PHD2 assay was performed similarly using the PHD2 protein isoform (the $2 \mathrm{X}$ enzyme solution contained $4.0 \mathrm{nM}$ PHD2, $0.2 \mathrm{mg} / \mathrm{ml} \mathrm{BSA}, 400 \mu \mathrm{M}$ ascorbic acid, $1.25 \mu \mathrm{g} / \mathrm{ml} \mathrm{FeCl}_{2}, 0.3 \mathrm{mM}$ CHAPS, and $50 \mathrm{mM} \mathrm{KCl}$ in $50 \mathrm{mM}$ HEPES at $\mathrm{pH}$ 7.5) and HIF $1 \alpha$ protein (the $2 \mathrm{X}$ substrate solution contained $50 \mathrm{nM}$ Cy5-labeled HIF $1 \alpha$-CODDD, $50 \mathrm{nM}$ VBC, $1 \mu \mathrm{g} / \mathrm{ml}$ streptavidin-Eu, $1 \mu \mathrm{M}$ $\alpha$-ketoglutarate, $0.3 \mathrm{mM}$ CHAPS, and $50 \mathrm{mM} \mathrm{KCl}$ in $50 \mathrm{mM}$ HEPES at $\mathrm{pH}$ 7.5).

The human PHD1 assay was performed similarly using the PHD1 protein isoform (the $2 \mathrm{X}$ enzyme solution contained $10 \mathrm{nM}$ PHD1, $0.2 \mathrm{mg} / \mathrm{ml} \mathrm{BSA}, 400 \mu \mathrm{M}$ ascorbic acid, $1.25 \mu \mathrm{g} / \mathrm{ml} \mathrm{FeCl}_{2}, 0.3 \mathrm{mM}$ CHAPS, $1 \mathrm{mM}$ tris(2-carboxyethyl)phosphine hydrochloride [TCEP], and $50 \mathrm{mM} \mathrm{KCl}$ in $50 \mathrm{mM}$ HEPES at $\mathrm{pH} 7.5$ ) and HIF $1 \alpha$ protein (the $2 \mathrm{X}$ substrate solution contained $50 \mathrm{nM}$ Cy5-labeled HIF $1 \alpha$-CODDD, $50 \mathrm{nM}$ VBC, $1 \mu \mathrm{g} / \mathrm{ml}$ streptavidin-Eu, $0.3 \mu \mathrm{M} \alpha$-ketoglutarate, $0.3 \mathrm{mM}$ CHAPS, and $50 \mathrm{mM} \mathrm{KCl}$ in $50 \mathrm{mM}$ HEPES at $\mathrm{pH}$ 7.5). Slight changes included the addition of $0.5 \mathrm{mM}$ final TCEP to the reaction, and plates were read on the EnVision (PerkinElmer) after a 40-minute reaction time.

A modified version of the screening assay was used to examine the mode of inhibition for GSK1278863. Using a 384-well plate (no. 3637; Corning Life Sciences, Tewksbury, MA), PHD3/Cofactor mix (2.33X final concentration in $50 \mathrm{mM}$ HEPES, $\mathrm{pH} 7.5$, with $50 \mathrm{mM} \mathrm{KCl}$ ) was incubated at room temperature for 1 minute with GSK1278863A (10 point, 3 -fold serial dilution in $25 \%$ DMSO, $7 \mathrm{X}$ final concentration) or $25 \%$ DMSO. The enzymatic reaction was initiated upon the addition of substrate (2.33X final concentration) resulting in a final volume of $7 \mu \mathrm{l}$. The LANCE ratio values were measured using a PerkinElmer EnVision (excitation at $320 \mathrm{~nm}$, emission at 665 and $615 \mathrm{~nm}$ ). Final concentrations of the PHD3/Cofactor mix consisted of $5 \mathrm{nM}$ enzyme, $0.1 \mathrm{mg} / \mathrm{ml} \mathrm{BSA}, 5 \mu \mathrm{M} \mathrm{FeCl}_{2}, 200 \mu \mathrm{M}$ ascorbic acid, $70 \mathrm{nM}$ biotin-VBC, $0.6 \mu \mathrm{g} / \mathrm{ml}$ streptavidin-Eu, and $43 \mathrm{nM}$ Cy5-HIF-2 $\alpha$ CODDD. The top dose of GSK1278863A tested was $12.5 \mu \mathrm{M}$. The substrate mix consisted of a 5 point, 3 -fold serial dilution in $\mathrm{ddH}_{2} \mathrm{O}$ of $\alpha$-ketoglutarate, where the top concentration tested was $200 \mu \mathrm{M}$.

The percentage inhibition data were determined from the slope of the progress curve, typically ranging from 5 to 40 minutes. The $\mathrm{IC}_{50}$ was determined by fitting the percentage inhibition data to a two-parameter 
$\mathrm{IC}_{50}$ equation. GSK1278863 $\mathrm{IC}_{50}$ values were then plotted as a function of $\alpha$-ketoglutarate concentration divided by its $K_{\mathrm{m}}^{\text {app }}$ value to determine the inhibition pattern and calculate $K_{\mathrm{i}}^{\text {app }}$. The data are best fit by the Cheng and Prusoff (1973) equation for competitive inhibition:

$$
\mathrm{IC}_{50}=\frac{K_{i}}{1+\left(\frac{[\mathrm{S}]}{K_{\mathrm{m}}}\right)}
$$

A second testing under similar conditions resulted in the same conclusion. PHD2 testing consisted of a 5-minute preincubation with GSK1278863A at a top dose of $80 \mu \mathrm{M}$. The final enzyme concentration of PHD2 was $2 \mathrm{nM}$, Cy5-HIF-1 $\alpha$ CODDD $(60 \mathrm{nM})$ was used in place of Cy5-HIF-2 $\alpha$ CODDD, and the top $\alpha$-ketoglutarate concentration tested was $6 \mu \mathrm{M}$.

Measurement of the intrinsic dissociation rate constant $\left(k_{\text {off }}\right)$ of GSK1278863A from PHDs was determined by rapid dilution. For part 1a, PHD3/Cofactor mix (1.33X final concentration in $50 \mathrm{mM}$ HEPES, $\mathrm{pH} 7.5$, with $50 \mathrm{mM} \mathrm{KCl}$ ) was incubated for 30 minutes with DMSO or $10 \mathrm{X}$ inhibitor (4X final concentration diluted in 50\% DMSO) at room temperature in a deep-well 96 -well plate. After a 30 -minute incubation, the reactions were diluted 100 -fold with buffer plus cofactors (1.11X final concentration). The concentrations of PHD3 and 10X inhibitor were 0.6 and $2.5 \mu \mathrm{M}$, respectively, during the incubation and subsequently diluted to 6 and $25 \mathrm{nM}$.

For part 1b, PHD3/Cofactor mix was diluted 100-fold ( $6 \mathrm{nM}$ final) and then incubated with $10 \mathrm{X}$ inhibitor $(2.5 \mu \mathrm{M})$ for 30 minutes. In part $2,9 \mu \mathrm{l}$ of the diluted incubation mixes from part $1 \mathrm{a}$ and $1 \mathrm{~b}$ were added to a 384-well plate (no. 3637; Corning Life Sciences) containing $1 \mu \mathrm{l}$ of substrate mix (10X final concentration in $50 \mathrm{mM}$ HEPES, $\mathrm{pH} 7.5$ with $50 \mathrm{mM} \mathrm{KCl}$ ) with or without $0.1 \mathrm{X}$ inhibitor. The LANCE ratio values were measured using a PerkinElmer Envision (excitation at $320 \mathrm{~nm}$, emission at 665 and $615 \mathrm{~nm}$ ).

Final concentrations after part 2 of the reaction consisted of $5.4 \mathrm{nM}$ PHD3, $0.09 \mathrm{mg} / \mathrm{ml} \mathrm{BSA}, 4.5 \mu \mathrm{M} \mathrm{FeCl}_{2}$, and $180 \mu \mathrm{M}$ ascorbic acid for the PHD3/Cofactor mix. GSK1278863A was tested at final concentrations of $2250 \mathrm{nM}(10 \mathrm{X})$ and $22.5 \mathrm{nM}(0.1 \mathrm{X})$. The substrate mix consisted of $35 \mathrm{nM}$ biotin-VBC, $0.6 \mu \mathrm{g} / \mathrm{ml}$ streptavidin-Eu, $35 \mathrm{nM}$ Cy5-HIF-2a CODDD, and $60 \mu \mathrm{M} \alpha$-ketoglutarate. Data are reported as $n=4$ determinations, $n=3$ used the prior conditions; whereas $n=1$ was tested using 450-4.5 nM PHD3 and GSK1278863A where $\alpha$-ketoglutarate was held at $500 \mathrm{mM}$.

The half-life was determined by fitting the progress curve to a fixed steady-state velocity equation for time-dependent inhibition.

$$
[P]=v_{s} t+\frac{v_{i}-v_{s}}{k_{o b s}}\left[1-\exp \left(k_{o b s} t\right)\right]+\text { background }
$$

PHD2 testing contained slight experimental adjustments to the PHD3 protocol. From part 1a, a portion of the PHD2/DMSO sample was diluted with 100 -fold dilution buffer containing 1) $0 \mathrm{X}$ inhibitor, 2) $0.1 \mathrm{X}$ inhibitor, or 3) 10X inhibitor while the PHD2/10X inhibitor sample was diluted with buffer containing $0 \mathrm{X}$ inhibitor only. Steps part $1 \mathrm{~b}$ and the addition of $0.1 \mathrm{X}$ inhibitor to the substrate mix in part 2 were removed. The final concentrations after part 2 were $1.08 \mathrm{nM}$ PHD2, $900 \mathrm{nM} \alpha$-ketoglutarate, and $35 \mathrm{nM}$ Cy5-HIF- $1 \alpha$ CODDD versus HIF$2 \alpha$. GSK1278863A was tested at final concentrations of 112.5 (10X) and $1.13 \mathrm{nM}(0.1 \mathrm{X})$.

Factor-Inhibiting HIF. GSK1278863 (10 point, 3-fold serial dilution in $50 \%$ DMSO, 15X final concentration) or 50\% DMSO was added to $1.1 \mathrm{ml}$ MicroTubes in strips of 12 followed by the addition of human FIH/Cofactor mix (4X final concentration in $50 \mathrm{mM}$ HEPES, $\mathrm{pH} 7.5$, with $50 \mathrm{mM} \mathrm{KCl}$ ). The enzyme plus inhibitor mix was incubated at room temperature for 30 minutes. Substrate mix (1.4X final concentration in $50 \mathrm{mM}$ HEPES, $\mathrm{pH} 7.5$, with $50 \mathrm{mM} \mathrm{KCl}$ ) was added to the MicroTubes yielding a $32 \mu \mathrm{l}$ final reaction volume. Filter paper cut in strips of 12 and saturated with $30 \mathrm{mM} \mathrm{Ca}(\mathrm{OH})_{2}$ were quickly added to the MicroTubes (without touching the reaction mix at the bottom of the tube) and capped. After 25 minutes, the filter paper was removed, placed in a vial with scintillation cocktail, and the released ${ }^{14} \mathrm{CO}_{2}$ captured on the filter paper was counted in a liquid scintillation spectrometer. The final concentrations of the FIH/Cofactor mix were $50 \mathrm{nM}$ enzyme, $0.25 \mathrm{mg} / \mathrm{ml} \mathrm{BSA}, 10 \mu \mathrm{M} \mathrm{FeCl}_{2}$, and $1 \mathrm{mM}$ ascorbic acid. The substrate mix consisted of $200 \mu \mathrm{M}$ HIF-1 $\alpha$ (D788L822), $10 \mu \mathrm{M} \alpha$-keto[1-14C] glutarate, and $50 \mu \mathrm{M} \alpha$-ketoglutarate. The final concentration of $\alpha$-ketoglutarate in the assay was set to be equivalent to $\sim 2 \times K_{\mathrm{m}}^{\mathrm{app}}$. The percentage inhibition data were determined from the total counts after a 25 -minute reaction. The $\mathrm{IC}_{50}$ value was determined by fitting the percentage inhibition data to a two-parameter $\mathrm{IC}_{50}$ equation.

The ability of GSK1278863 to inhibit human FIH in a timedependent manner was determined using the previously described experimental procedure in addition to an $\mathrm{IC}_{50}$ value determined after 1 minute of enzyme plus inhibitor incubation.

Collagen Prolyl Hydroxylase. Human CP4H/Cofactor mix (4X final concentration in $50 \mathrm{mM}$ HEPES, $\mathrm{pH} 7.5$, with $50 \mathrm{mM} \mathrm{KCl}$ ) was incubated at room temperature for 30 minutes with GSK1278863 (10 point, 3-fold serial dilution in 50\% DMSO, $15 \mathrm{X}$ final concentration) or $50 \%$ DMSO. Substrate mix (1.4X final concentration in $50 \mathrm{mM}$ HEPES, pH 7.5, with $50 \mathrm{mM} \mathrm{KCl)} \mathrm{was} \mathrm{added} \mathrm{to} \mathrm{the} \mathrm{plate} \mathrm{yielding} \mathrm{a}$ $32 \mu \mathrm{l}$ final reaction volume. After 20 minutes, the reaction was quenched by the addition of $0.67 \%$ final $\mathrm{H}_{3} \mathrm{PO}_{4}$. Product formation was detected using reverse-phase high-performance liquid chromatography (Ex $336 \mathrm{nM}$ and $\mathrm{Em} 517 \mathrm{nM}$ ). The final concentrations of the $\mathrm{CP} 4 \mathrm{H} /$ Cofactor mix were $21.11 \mathrm{nM}$ enzyme, $1 \mathrm{mg} / \mathrm{ml} \mathrm{BSA}, 50 \mu \mathrm{M}$ $\mathrm{FeCl} 2,2 \mathrm{mM}$ ascorbic acid, $100 \mu \mathrm{M}$ dithiothreitol (DTT), and $100 \mu \mathrm{g} / \mathrm{ml}$ catalase. The substrate mix consisted of $100 \mu \mathrm{M}$ dansyl-GFPG-Oet and $110 \mu \mathrm{M} \alpha$-ketoglutarate. The percentage inhibition data were determined from the ratio of product to substrate after a 20 -minute reaction. The $\mathrm{IC}_{50}$ value was determined by fitting the percentage inhibition data to a two-parameter $\mathrm{IC}_{50}$ equation.

Inhibition by GSK1278863 against human $\mathrm{CP} 4 \mathrm{H}$ was confirmed using the radioactive ${ }^{14} \mathrm{CO}_{2}$ release assay similar to that described for FIH; however, the reaction was stopped after 20 minutes. The final concentrations of the CP4H/Cofactor mix were $20 \mathrm{nM}$ enzyme, $1 \mathrm{mg} / \mathrm{ml}$ BSA, $50 \mu \mathrm{M} \mathrm{FeCl}_{2}, 2 \mathrm{mM}$ ascorbic acid, $100 \mu \mathrm{M}$ dithiothreitol (DTT), and $100 \mu \mathrm{g} / \mathrm{ml}$ catalase. The substrate mix consisted of $100 \mu \mathrm{M}$ (P-PG) $10,20 \mu \mathrm{M} \alpha$-keto[1- $\left.{ }^{14} \mathrm{C}\right]$ glutarate and $90 \mu \mathrm{M} \alpha$-ketoglutarate. The final concentration of $\alpha$-ketoglutarate in the assay was set to be equivalent to $\sim 2 \mathrm{X} K_{\mathrm{m}}^{\mathrm{app}}$.

Serotonin (5HT)-2 Receptors. Because 5-hydroxytryptamine $2 \mathrm{~B}$ (5HT-2B) receptor agonism has been implicated in the pathogenesis of fenfluramine-induced valvulopathy in humans, we hypothesized it could be involved in the valve lesions we observed. SHSY5Y cells stably transfected with the appropriate 5HT2 receptor were plated in 384-well Nunc noncoated black-walled, clear-bottom plates with 16,000 cells per well in $100 \mu \mathrm{l} \alpha$ minimum essential medium + ribonucleosides (Gibco Invitrogen, Grand Island, NY) supplemented with $10 \%$ fetal bovine serum (Gibco Invitrogen) and $400 \mu \mathrm{g} / \mathrm{ml}$ Geneticin G418 (Gibco Invitrogen) and incubated overnight in a humidified incubator at $37^{\circ} \mathrm{C}$ and $5 \% \mathrm{CO}_{2}$. The cells were washed to remove all media. We added $50 \mu \mathrm{l}$ of buffer (Hanks' balanced salt solution, $20 \mathrm{mM}$ HEPES, $4.16 \mathrm{mM} \mathrm{NaHCO}_{3}, 2.5 \mathrm{mM}$ probenecid, $\mathrm{pH}$ 7.4; Sigma-Aldrich, St. Louis, MO) and then aspirated all but $10 \mu \mathrm{l}$. We added $30 \mu \mathrm{l}$ of loading dye $(250 \mu \mathrm{M}$ Brilliant Black, $2 \mu \mathrm{M}$ Fluo- 4 diluted in Hanks' balanced salt solution buffer; Molecular Devices, Sunnyvale, CA), and the cells were returned to the incubator for 1 hour. An 11-point 1:4 dilution series of test compounds was then added to the cells using the fluorimetric imaging plate reader (FLIPR; Molecular Devices), and the plates were returned to the incubator to equilibrate for 30 minutes.

For agonist assays, 5HT was diluted in buffer at $0.1 \mathrm{mM}$ and then diluted 4 -fold in buffer to generate an 11-point serial dilution. Six microliters of the dilution series was transferred into $95 \mu \mathrm{l}$ buffer. A signal test was performed on a yellow plate to check uniformity of the laser beam, with exposure length set to 0.05 seconds and varying light in the range of $0.5-0.8 \mathrm{~W}$ to obtain an average signal of $\sim 63,000$ 
fluorescence intensity units. A signal test was performed on the cell plate to check variability, with the exposure length set to 0.4 seconds and varying light in the range of $0.5-0.9 \mathrm{~W}$ to obtain a desirable signal of $\sim 6000-10,000$ fluorescence intensity units. The following program was then run on the FLIPR: 0.4 second exposure length; read every second for 60 counts for the first sequence, first interval; read every 3 seconds for 20 counts for the second interval; $10 \mu$ l addition of fluid. The $\mathrm{EC}_{50}$ values were determined from a four-parameter logistic curve fit using ActivityBase (IDBS, Boston, MA).

For antagonist assays, the following program was run on the FLIPR: 0.4 second exposure length; read every second for 60 counts for the first sequence, first interval; read every 3 seconds for 20 counts for the second interval; $10 \mu \mathrm{l}$ addition of fluid. The $\mathrm{IC}_{50}$ values were determined from a four-parameter logistic curve fit using ABase.

Mouse Plasma EPO and Hematologic Counts. B6D2F1/Crl mice were ordered from Charles River Laboratories (Raleigh, NC).

EPO and VEGF. Normal female B6D2F-1 mice $(n=6)$ were dosed by oral gavage with GSK1278863 at $60 \mathrm{mg} / \mathrm{kg}$, and blood was collected from euthanized animals by cardiac puncture into EDTA tubes. Vehicle-treated animals were sampled at 6 hours only. Platelet-poor plasma (PPP) was prepared for EPO and VEGF enzyme-linked immunosorbent assay (ELISA) time course analysis as follows. The samples were centrifuged at $1000 \mathrm{~g}$ for 10 minutes, and the plasma fraction was removed to a new tube. The plasma samples were further centrifuged at $10,000 \mathrm{~g}$ for 10 minutes. The supernatant (PPP) was removed to a fresh tube and stored at $-80^{\circ} \mathrm{C}$. The PPP samples were analyzed for EPO and VEGF protein concentrations using Meso-Scale Discovery mouse ELISA plates (MSD, Rockville, MD) according to the manufacturer's instructions and were read on the MSD SECTOR Imager 6000.

Data from the MSD SECTOR Imager $6000(n=1$ well for each mouse) were imported into an Excel spreadsheet for analysis. Sample EPO and VEGF concentrations in $\mathrm{pg} / \mathrm{ml}$ were determined from a regression fit of the EPO or VEGF standard curves. Averages and standard errors were calculated and plotted.

Blood Counts - Reticulocytes and Hemoglobin. Groups of five female B6D2F1 mice were dosed orally once per day with either vehicle (1\% methylcellulose) or GSK1278863 at 3,10 or $30 \mathrm{mg} / \mathrm{kg}$. Animals were dosed for eight consecutive days, and blood was collected from euthanized animals by cardiac puncture on day 9 into EDTA tubes. Samples were analyzed on the Advia blood analyzer (Siemens Healthcare GmbH, Erlangen, Germany) to determine blood cell parameters.
Blood parameters were imported from the Advia 120 blood analyzer into an Excel spreadsheet (Microsoft, Redmond, WA) for analysis using Hemacalc, an Excel macro. The mean, S.D., and S.E. were calculated using standard formulas. $P$ values were determined using Student's $t$ test on the square roots of the sample values. The S.E. from Hemacalc was used to display error bars on the graphs.

\section{Screening 14-Day Oral Toxicity Studies}

GSK1278863. Groups of male or female Sprague-Dawley rats (4 per group; obtained from Charles River Laboratories) were given 0 (vehicle), or $10,30,60,100,250$, or $500 \mathrm{mg} / \mathrm{kg}$ per day GSK1278863 in $1 \%$ methylcellulose once daily for up to 14 days by oral gavage.

Other PHD Inhibitors (Compounds A, B, C, D, E, and F). Four groups/compound of male Sprague-Dawley rats (4 per group) were given 0 (vehicle), or three dose levels per compound (ranging from 10 to $300 \mathrm{mg} / \mathrm{kg}$ per day) in $1 \%$ methylcellulose once daily for up to 14 days by oral gavage.

28-Day Oral Toxicity Studies (Compound A). Five groups of male and female CD-1 mice (10/sex/group; obtained from Charles River Laboratories) were given 0 (vehicle), or four dose levels (ranging from 3 to $100 \mathrm{mg} / \mathrm{kg}$ per day) in $1 \%$ methylcellulose once daily for up to 28 days by oral gavage.

Four groups of male and female beagle dogs (3/sex/group; obtained from Marshall BioResources, North Rose, NY) were given 0 (empty gelatin capsule), or three dose levels (ranging from 15 to $120 \mathrm{mg} / \mathrm{kg}$ per day) once daily for up to 28 days by oral capsule.

The toxicity studies included standard study end points: clinical observations, body weights, hematology and clinical chemistry, organ weights, macroscopic and microscopic observations, and toxicokinetics (performed on separate subsets of animals in the rodent studies).

\section{Results}

\section{Identification and Biochemical Characterization of GSK1278863}

A novel series of pyrimidinetrione inhibitors was designed to potently inhibit the PHDs, forming tight-binding interactions with the catalytic iron and a cofactor-pocket arginine residue (Fig. 2). GSK1278863 was ultimately identified after extensive optimization of potency, selectivity, and drug metabolism and pharmacokinetics properties (as described further below).

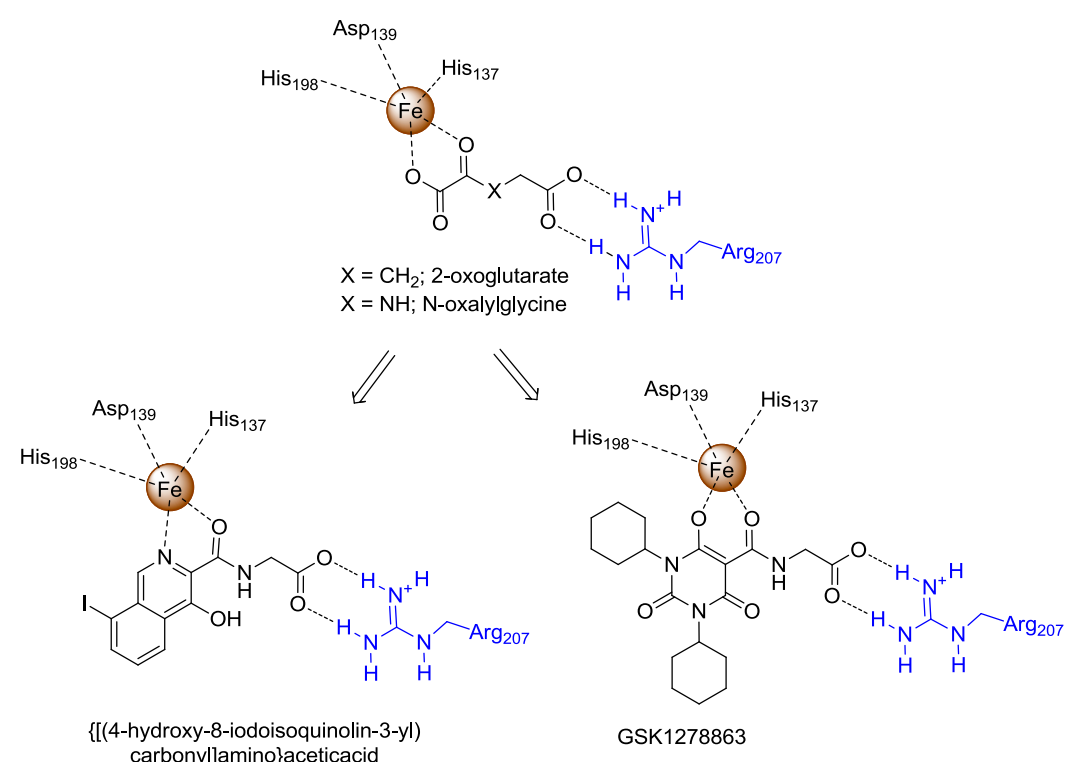

Fig. 2. GSK1278863 and isoquinolineglycinamide binding compared with 2-oxoglutarate (2-OG) and N-oxalylglycine (NOG), 2-OG and NOG along with isoquinolineglycinamides form five-membered chelates with the catalytic iron residue. GSK1278863 is designed to form a six-membered chelate with iron. All molecules form a conserved salt bridge with the cofactor binding pocket arginine residue. 


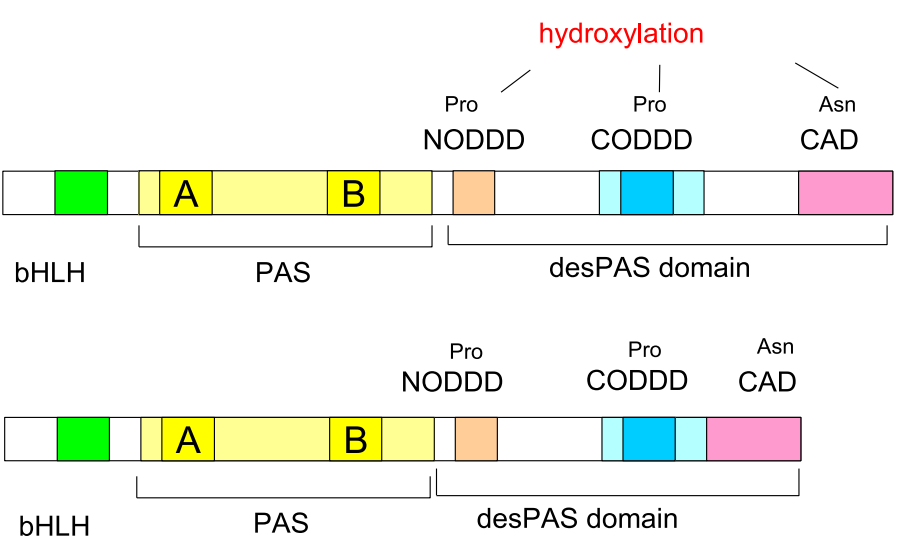

A high-throughput homogeneous fluorescence resonance energy transfer (FRET) assay was developed to measure human PHD enzymatic activity (Pappalardi et al., 2008, 2011). The primary substrate is the HIF CODDD (Fig. 3), which contains a proline residue hydroxylated by PHD. All biochemical studies conducted with PHD1 and PHD2 used HIF $1 \alpha$ CODDD as the substrate, and PHD3 used HIF2 $\alpha$ CODDD. The HIF CODDD substrates are labeled with the fluorescent group Cy5. When hydroxylated, Cy5-HIF CODDD is recognized by the biotin-labeled VBC complex. Addition of streptavidin-Eu chelate results in proximity of Eu to Cy5 in the product, allowing for detection by FRET. A ratio of Cy5 to $\mathrm{Eu}$ fluorescence emission, the lanthanide chelate excite (LANCE) ratio is the ultimate readout, as this normalized parameter has significantly less variance than the Cy5 emission alone.

The inhibitory mechanism of GSK1278863 against $\alpha$-KG for PHD3 was examined by plotting GSK1278863 IC $_{50}$ values as a function of $\alpha$-KG concentration divided by its $K_{\mathrm{m}}^{\mathrm{app}}$ value. GSK1278863 IC $_{50}$ values increased in a manner consistent with an $\alpha$-KG-competitive mode of inhibition, where the data are best fit by eq. 1, the Cheng and Prusoff (1973) equation for competitive inhibition, yielding a $K_{\mathrm{i}}^{\text {app }}$ value of $92 \mathrm{nM}$ for PHD3 (Fig. 4, left panel).

GSK1278863 demonstrated time-dependent inhibition against PHD3, as evidenced by a large increase in potency after a 30-minute enzyme:inhibitor preincubation, shifting the $K_{\mathrm{i}}^{\text {app }}$ from $92 \mathrm{nM}$ (1 minute enzyme:inhibitor preincubation) to $1.8 \mathrm{nM}$ (Table 1 ). The $K_{\mathrm{i}}^{*}$ app values of 1.8 and $7.3 \mathrm{nM}$ calculated using the Cheng-Prusoff equation for competitive inhibition against PHD3 and PHD2, respectively, may underestimate the true $K_{\mathrm{i}}\left(K_{\mathrm{i}}^{*}\right)$ under these conditions if the $\mathrm{EI}^{*}$
HIF1a

Fig. 3. Schematic diagrams of HIF $1 \alpha$ and HIF $2 \alpha$ protein structure motifs. bHLH, basic helix-loop-helix; CAD, C-terminal activation domain; CODDD, C-terminal oxygen-dependent degradation domain; NODDD, N-terminal oxygen-dependent degradation domain; PAS, Per-Arnt-Sim domain. conformation was not fully obtained under the standard assay conditions which contained a 30-minute enzyme:inhibitor preincubation (Table 1).

To determine whether the observed time-dependent behavior was the result of slow-binding reversible inhibition between GSK1278863 and PHD3, a preformed GSK1278863-PHD3 complex was rapidly diluted into substrate mix where the $\alpha$-KG concentration was roughly $6 \times K_{\mathrm{m}}^{\text {app }}$ to prevent rebinding (Copeland, 2005). Upon dilution, recovery of PHD3 activity was observed, indicating that GSK1278863 is a reversible inhibitor of PHD3.

The observed rate of recovery, $k_{\mathrm{obs}}$, was obtained by fitting the data to a single exponential model. Under experimental conditions, $k_{\text {obs }}$ reflects the intrinsic dissociation rate $\left(k_{\text {off }}\right)$ of the inhibitor from PHD3. The residence half-life value $\left(t_{1 / 2}\right)$ is calculated from $k_{\text {off }}$ based on the equation $t_{1 / 2}=0.693 / k_{\text {off }}$; $t_{1 / 2}=132 \pm 19$ minutes $(n=4)$ for PHD3 (Fig. 4, right panel). This $t_{1 / 2}$ value indicates that GSK1278863 does not dissociate instantaneously from the PHD3 enzyme, resulting in prolonged inhibition of PHD3, which may impact the in vivo pharmacologic activity of this compound. GSK1278863 was also found to be an $\alpha$-KG competitive, reversible inhibitor of PHD2 with a residence half-life, $t_{1 / 2}=92 \pm 43$ minutes $(n=2)$ (see Supplemental Data).

Because GSK1278863 was designed as a cofactor mimetic, its ability to inhibit additional members of the irondependent $\alpha$-KG- dioxygenase superfamily was assessed. The $\mathrm{IC}_{50}$ values were determined against human $\mathrm{CP} 4 \mathrm{H}$ using a procollagen peptide substrate and human FIH using a HIF $1 \alpha$ peptide $\left(\mathrm{D}_{788}-\mathrm{L}_{822}\right)$ after 30 minutes of enzyme plus inhibitor preincubation. The resulting $\mathrm{IC}_{50}$ values of $9.8 \mu \mathrm{M}$ for $\mathrm{FIH}$ and $>200 \mu \mathrm{M}$ for $\mathrm{CP} 4 \mathrm{H}$ show that
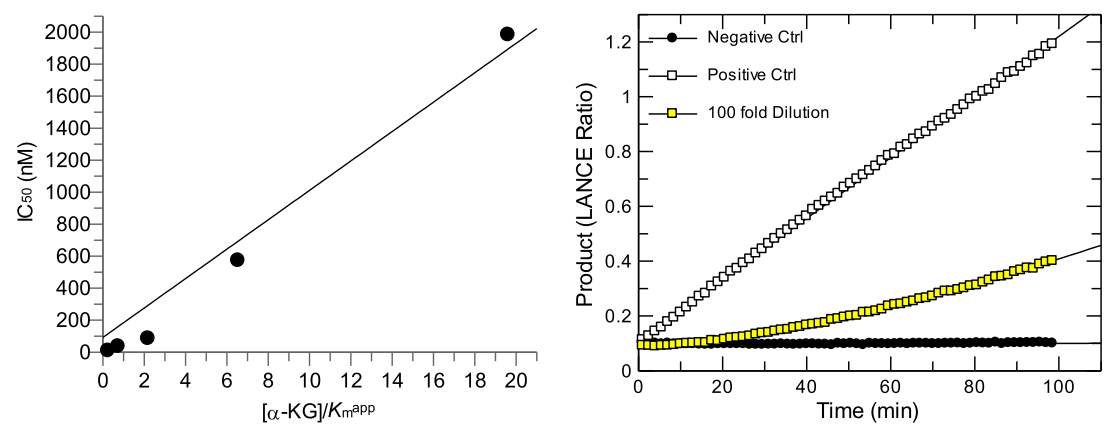

Fig. 4. Mode of inhibition against PHD3 (left) where GSK1278863 IC $_{50}$ values were plotted as a function of $[\alpha-\mathrm{KG}] / K_{\mathrm{m}}^{\mathrm{app}}$ and fit to an equation for competitive inhibition. Determination of the dissociation half-life value $\left(t_{1 / 2}\right)$ for GSK1278863 from PHD3 by rapid dilution method (right). The yellow squares show the enzyme activity after dilution fit to an equation to determine the observed rate of recovery $\left(k_{\mathrm{obs}}\right)$. Control reactions at $10 \mathrm{x} \mathrm{IC}_{50}$ (black circles) and $0.1 \times \mathrm{IC}_{50}$ (white squares) represent enzyme activity before dilution and after dilution if the compound was rapidly reversible. 
TABLE 1

Inhibitory activity of GSK1278863 against $\alpha$-KG-dependent iron dioxygenases after a 30-minutes of enzyme with inhibitor preincubation

$K_{\mathrm{i}} \mathrm{a}^{\mathrm{pp}}$ values were calculated based on the equation: $K_{\mathrm{i}}=\mathrm{IC}_{50} /\left(1+\left([\mathrm{S}] / K_{\mathrm{m}}\right)\right.$ for a competitive inhibitor (Cheng and Prusoff, 1973).

\begin{tabular}{llcccrl}
\hline Enzyme & \multicolumn{1}{c}{ Substrate } & $\alpha-\mathrm{KG} K_{\mathrm{m}}(\mathrm{nM})$ & $\mathrm{IC}_{50} \pm$ S.D. $(\mathrm{nM})$ & $K_{\mathrm{i} \text { app }}(\mathrm{nM})$ & $n$ & Assay Format \\
\hline PHD1 & HIF1 $\alpha$ CODDD & $71 \pm 12^{a}$ & $3.5 \pm 0.6$ & $1.8 \pm 0.3$ & 2 & FRET \\
PHD2 & HIF1 $\alpha$ CODDD & $188 \pm 14^{a}$ & $22.2 \pm 13.4$ & $7.3 \pm 4.5$ & 10 & FRET \\
PHD3 & HIF2 $\alpha$ CODDD & $7500 \pm 2000^{a}$ & $5.5 \pm 5.1$ & $1.8 \pm 1.7$ & 10 & FRET \\
FIH & HIF- $1 \alpha\left(D_{788}-L_{822}\right)$ & $32 \pm 6$ & $9800 \pm 7500$ & $3200 \pm 2500$ & 2 & ${ }^{14} \mathrm{CO}_{2}$ capture \\
CP4H & Procollagen peptide & $53 \pm 1$ & $>200,000$ & $>63,000$ & 7 & $\mathrm{HPLC}^{14} \mathrm{CO}_{2}$ \\
\hline
\end{tabular}

HPLC, high-performance liquid chromatography.

${ }^{a}$ Reported in Pappalardi et al. (2011).

GSK1278863 is at least 1000 -fold selective for PHDs (Table 1).

\section{The Biology and Pharmacology of GSK1278863}

Induction of EPO. The immediate downstream effect of PHD inhibition in a cellular context is $\mathrm{HIF} \alpha$ subunit accumulation. Stabilization of HIF $1 \alpha$ and HIF2 $\alpha$ was determined by Western blot analysis of nuclear protein extracts after GSK1278863 treatment of Hep3B cells. Western blot analysis demonstrated that neither HIF $1 \alpha$ nor HIF $2 \alpha$ was detected in the vehicle-treated cells, and both HIF $1 \alpha$ and HIF $2 \alpha$ were visualized in the DFX-positive control-treated cells. Treatment with either 25 or $50 \mu \mathrm{M}$ GSK1278863 for 6 hours resulted in the accumulation of both HIF $1 \alpha$ and HIF $2 \alpha$ subunits (Fig. 5). These results demonstrate that prolyl hydroxylase inhibition by GSK1278863 treatment of cells results in the immediate downstream effect of $\mathrm{HIF} \alpha$ subunit stabilization.

Moving from an in vitro context to in vivo context, normal female B6D2F1 mice were administered a single oral dose of GSK1278863 at $60 \mathrm{mg} / \mathrm{kg}$, and blood samples were collected at intervals between 4 and 30 hours after dosing $(n=6$ mice/time point for GSK1278863-treated mice; vehicle-treated mice were sampled at 6 hours only). After the treatment with GSK1278863, the EPO protein levels peaked at 12 hours after dosing (Fig. 6), representing an 11.2-fold increase with a mean plasma concentration of $1303 \mathrm{pg} / \mathrm{ml}$. Additionally, the EPO values at all other time points remained elevated by 1.9- to 2.9fold relative to the vehicle-treated mice. The VEGF concentrations remained generally unchanged across the time course and were only slightly higher than those of vehicle-treated mice. These data indicate that a single $60 \mathrm{mg} / \mathrm{kg}$ dose of GSK1278863 results in a significant but transient increase in circulating levels of EPO, with minimal impact on VEGF concentrations.

In Vivo Increases in Reticulocyte Count and Hemoglobin. The pharmacologic consequence of repeated daily treatment of normal $\mathrm{B} 6 \mathrm{D} 2 \mathrm{~F} 1$ mice with vehicle or GSK1278863 (3, 10, or $30 \mathrm{mg} / \mathrm{kg}$ per day) for 8 days is shown in Fig. 7. Approximately 24 hours after the final dose, the mice were euthanized, and their blood was collected by cardiac puncture and analyzed on the Advia Blood Analyzer. Statistically significant increases in reticulocytes were observed in the compound-treated mice $(211 \%, 544 \%$, and $673 \%$ over placebo) administered 3,10 , and $30 \mathrm{mg} / \mathrm{kg}$ GSK1278863, respectively (Fig. 7A).

Consistent with the observed reticulocyte increases, the hemoglobin levels were also found to be significantly elevated
(12\%, $17 \%$, and $13 \%)$ relative to vehicle-treated mice after dosing with 3,10 , and $30 \mathrm{mg} / \mathrm{kg}$ per day GSK1278863, respectively (Fig. 7B). Red blood cell counts and hematocrit were statistically significantly elevated in mice as well. Similar responses in reticulocytes and red blood cell mass parameters were evident in rats, beagle dogs, and cynomolgus monkeys after comparable treatment durations, with responses progressing as dosing duration became more chronic (data not shown).

\section{Pharmacokinetics of GSK1278863 in Different Animal Species}

When dosed intravenously, GSK1278863 showed low blood clearance in the mouse, rat, dog, and monkey $[<1 \%$ hepatic blood flow (Qh) in mouse and rat, $\sim 3 \% \mathrm{Qh}$ in dog, and $\sim 19 \% \mathrm{Qh}$ in monkey] (Table 2). The steady-state volume of distribution $(\sim 0.3-0.8 \mathrm{l} / \mathrm{kg})$ was less than or approximately equal to the total body water in all four preclinical species.

Pharmacokinetic parameters were also determined for GSK1278863 after oral suspension administration to rats (Table 3). Unless otherwise indicated, the rats were fasted overnight before oral administration of GSK1278863. The systemic exposure of GSK1278863 was similar in the rat after
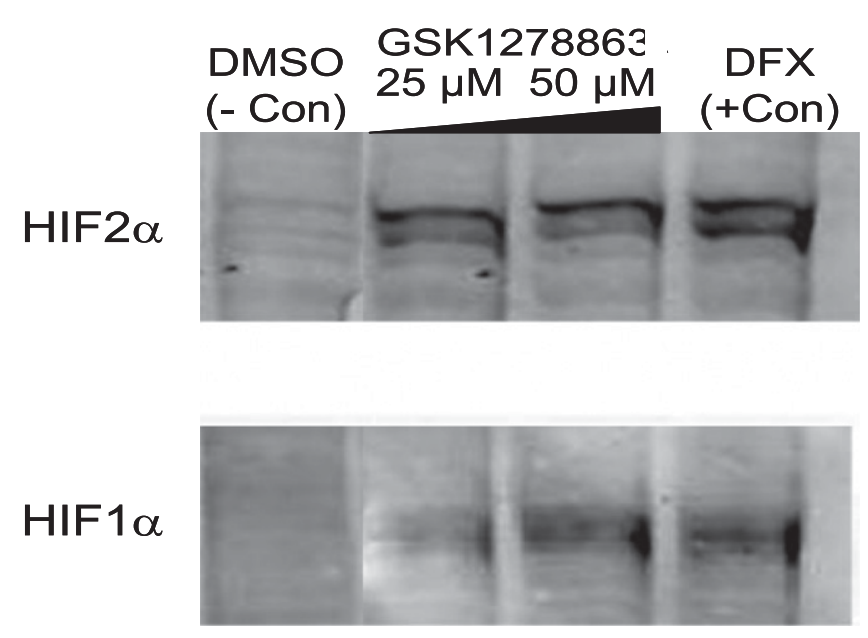

Fig. 5. HIF $1 \alpha$ and HIF $2 \alpha$ stabilization in Hep3B cells after treatment with GSK1278863. Nuclear extracts were prepared from Hep3B cells treated for 6 hours as indicated, and Western blots were performed to detect HIF $1 \alpha$ and HIF2 $\alpha$. An equal amount of nuclear lysate was loaded to each lane for the Western blot analysis. Under normoxic conditions, HIF $1 \alpha$ and HIF $2 \alpha$ were not present, but both were detected after treatment with GSK1278863 or DFX, with a possible concentrationdependent increase of HIF $1 \alpha$. 


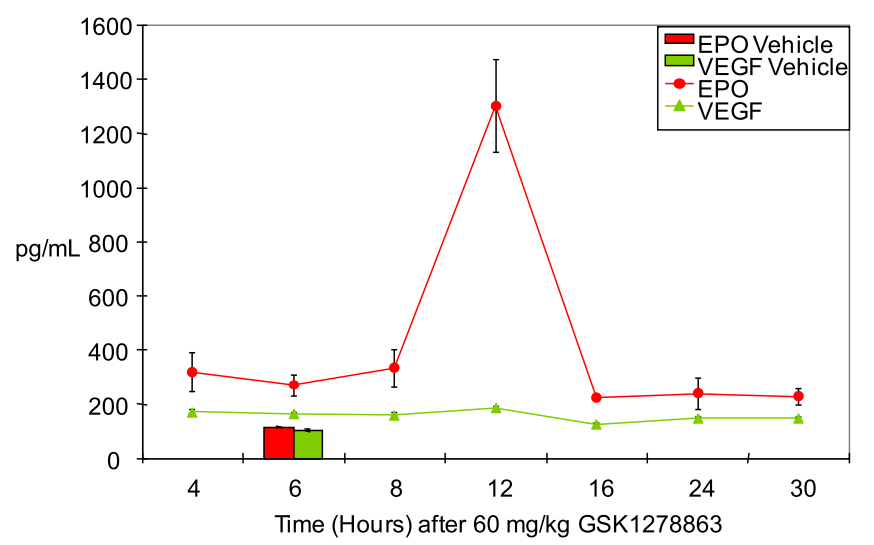

Fig. 6. EPO and VEGF in plasma of mice treated with vehicle or a single oral $60 \mathrm{mg} / \mathrm{kg}$ dose of GSK1278863. Normal female B6D2F1 mice $(n=6)$ were administered a single oral dose of $60 \mathrm{mg} / \mathrm{kg}$ of GSK1278863, and PPP was collected at the indicated time points. PPP was collected 6 hours after vehicle treatment. EPO and VEGF were detected by MSD ELISA. The average and S.E. are depicted.

oral solution dosing $(1.6 \mathrm{mg} / \mathrm{kg})$ and oral suspension dosing $(31.1 \mathrm{mg} / \mathrm{kg})$ of crystalline GSK1278863, suggesting a minimal impact of solubility and dissolution rate on the bioavailability of the drug molecule. Similar favorable comparisons between orally dosing a solution versus a suspension of crystalline solid were observed in both mice and dogs (see Supplemental Tables 1 and 2).

\section{Toxicology}

In screening 14-day oral toxicity studies with once daily administration to Sprague-Dawley rats, GSK1278863 demonstrated an acceptable toxicity profile that supported candidate selection and continued development. In chronic oral toxicity studies, dose-limiting effects of GSK1278863 were the result of marked pharmacologically mediated increases in hematocrit and consisted of generalized vascular congestion, thrombosis, and/or multiorgan pathology. These findings are considered consequences of compromised blood flow and vascular perfusion consequent to high hematocrits and inferred high blood viscosity, and they represent a manageable clinical risk via the routine hematology monitoring and hemoglobin stopping criteria in place in clinical studies of GSK1278863.

In contrast, four compounds (compounds A, B, C, and D; Chai et al. (2007), Shaw et al. (2008); see Supplemental Fig. 2) of similar chemical structure and comparable on-target potencies induced cardiac valve lesions in oral toxicity studies in 14-day rats or 28-day mice and dogs. These lesions, which were observed in right and/or left atrioventricular valves and/or aortic valves, consisted of a spectrum of changes most notably including myxomatous thickening characterized by widened valve leaflets and/or neutrophilic or mixed inflammatory cell infiltrates (Fig. 8).

These valve lesions were not associated with an attached thrombus or thrombosis elsewhere in the heart, as has been described for the valvulopathy observed in 4-week rat toxicology studies conducted with the hyperglycosylated rHuEPO AMG-114 (Andrews et al., 2014a, Sinclair, 2013). Uncertainty over the relevance of these findings to humans resulted in an unfavorable risk assessment for continued development of these four compounds. Because valvulopathies are commonly
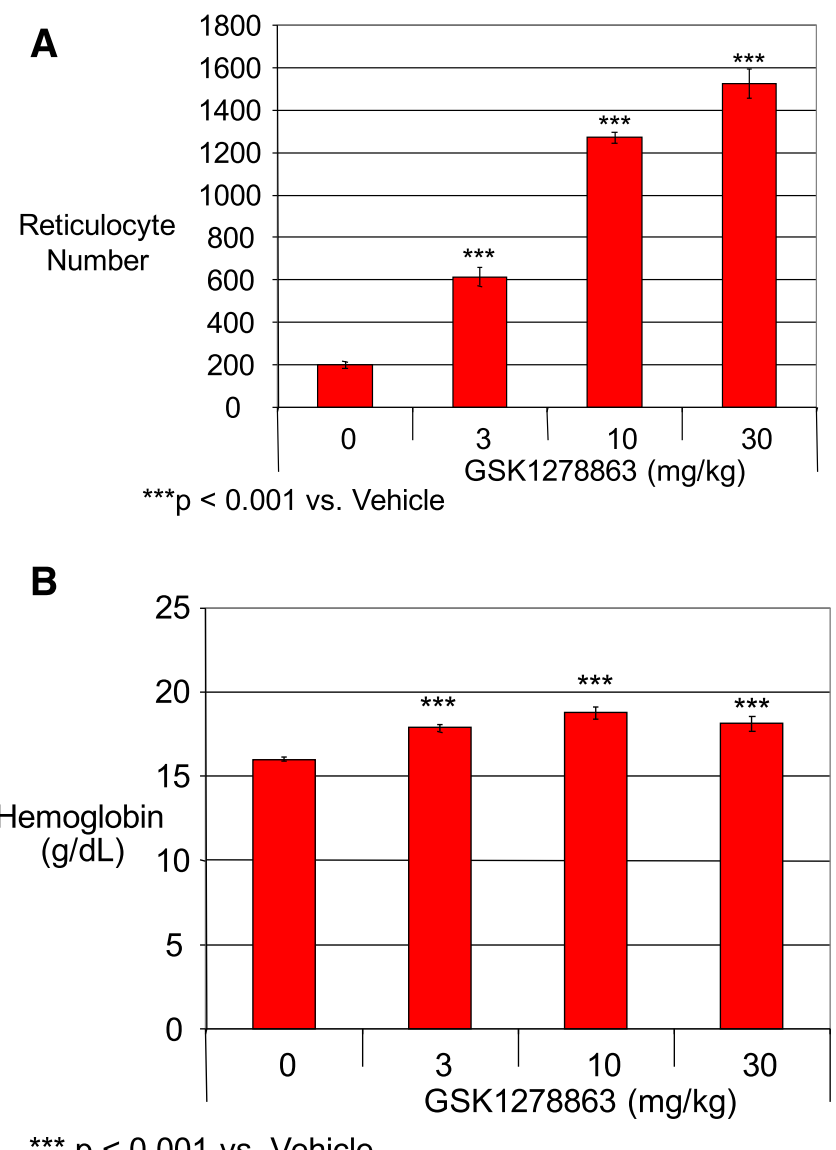

Fig. 7. Mouse reticulocytes and hemoglobin after eight daily oral doses of GSK1278863. Normal female B6D2F1 mice $(n=5)$ were administered eight daily oral doses of vehicle or GSK1278863at the doses indicated. Blood was analyzed on an Advia blood analyzer, and the mean and S.E. are plotted.

associated with several human connective tissue disorders (e.g., Ehlers Danlos, Marfans) (Glesby and Pyeritz, 1989; Ha et al., 1994; Myllyharju and Kivirikko, 2001; Lincoln et al., 2006), which are characterized by mutations in collagens and/or collagen processing genes, it was hypothesized that inhibitory activity on the closely related enzyme $\mathrm{CP} 4 \mathrm{H}$ may be contributory. Interestingly, these four compounds demonstrated moderate inhibitory activity on human $\mathrm{CP} 4 \mathrm{H}\left(\mathrm{IC}_{50}\right.$ of 2.5-63 $\mu \mathrm{M}$; PHD:CP4H selectivity of 20- to 1000-fold).

Prioritizing PHD:CP4H selectivity in our compound selection criteria led to the discovery of GSK1278863 (human $\mathrm{CP} 4 \mathrm{H} \mathrm{IC}_{50}>200 \mu \mathrm{M}$; PHD:CP4H selectivity $>9000$-fold),

TABLE 2

Summary of the pharmacokinetics of GSK1278863

Values are expressed as mean and S.D. of parameter, where appropriate $(n=3)$.

\begin{tabular}{lccccc}
\hline Species & $\mathrm{CL}^{\mathrm{b}}$ & $V_{\mathrm{dss}}$ & $T_{1 / 2}$ & MRT & Oral F (\%) \\
\hline & $\mathrm{ml} / \mathrm{min} / \mathrm{kg}$ & $l / k g$ & $h$ & $h$ & \\
Mouse $^{a}$ & 0.7 & 0.3 & $\mathrm{ND}$ & 7.8 & 88 \\
Rat & $0.2 \pm 0.02$ & $0.4 \pm 0.1$ & $33.5 \pm 6.2$ & $36.7 \pm 4.7$ & $\sim 100^{b}$ \\
Dog & $0.9 \pm 0.2$ & $0.5 \pm 0.1$ & $6.6 \pm 2.1$ & $8.8 \pm 2.7$ & $46 \pm 6$ \\
Monkey & $8.4 \pm 0.2$ & $0.8 \pm 0.1$ & $1.9 \pm 0.1$ & $1.6 \pm 0.1$ & $34 \pm 8$ \\
\hline
\end{tabular}

CL, clearance; MRT, mean residence time; ND, not determined; $V_{\mathrm{dss}}$, steady-state volume of distribution.

${ }^{a}$ Composite sampling design ( $n=3$ animals per time point).

${ }^{b}$ Noncrossover design, data estimated from mean i.v. data. 
TABLE 3

Mean oral pharmacokinetic parameters of GSK1278863 in the rat

Values are expressed as mean and S.D. of parameter, where appropriate $(n=3)$; serial sampling design in male SpragueDawley rats.

\begin{tabular}{cccccc}
\hline Dose & $C_{\max }$ & $T_{\max }{ }^{a}$ & $\mathrm{AUC}_{0-24 \mathrm{~h}}$ & $\mathrm{AUC}_{0-\infty}$ & DNAUC $_{0-24 \mathrm{~h}}$ \\
\hline$m g / k g$ & $\mu g / m l$ & $h$ & $\mu g . h / m l$ & $\mu g . h / m l$ & $\mu g . h / m l / m g / k g$ \\
$1.6^{b}$ & $2.86 \pm 0.51$ & 4.0 & $46.61 \pm 8.95$ & $106.63 \pm 19.97$ & 29.13 \\
$31.1^{c, d}$ & $62.40 \pm 3.78$ & 2.0 & $941.02 \pm 68.91$ & $\mathrm{ND}$ & 30.26 \\
\hline
\end{tabular}

$\mathrm{AUC}_{0-24 \mathrm{~h}}$, area under the plasma concentration-time curve within 0 to 24 hours; $\mathrm{AUC}_{0-\infty}$, area under the plasma concentration-time curve from time 0 to infinity; DNAUC0-24h, dose-normalized area under the plasma concentrationtime curve within 0 to 24 hours; ND, not determined since \% extrapolated $\mathrm{AUC}_{0-\infty}$ was high.

a $T_{\max }$ expressed as median.

${ }^{b}$ Solution in $2 \%$ DMSO, $20 \%$ (w/v) Captisol in water, $\mathrm{pH} \sim 7.0$.

${ }^{c}$ Suspension in $1 \%$ methylcellulose.

${ }^{d}$ Animals were not fasted overnight before dosing

which did not cause valvulopathy in 14- or 28-day rat oral toxicity studies or in dog or monkey studies of up to 9 months duration when dosed to maximum tolerated doses. In 3- and/or 6-month mouse and/or rat oral toxicity studies, a few GSK1278863-treated animals presented with thrombi in atria or ventricles that resulted in minimal secondary valve lesions in adjacent structures. Thromboses in these cases were considered complications from polycythemia. The resultant valvular changes were morphologically distinct in character and severity from those observed in studies with compounds A through D and were typical of those often observed in association with cardiac thrombosis.

In light of the implication of 5HT-2B receptor agonism in the pathogenesis of fenfluramine-induced valvulopathy in humans (Connolly et al., 1997), we tested GSK1278863 and compounds A through D for antagonism of 5HT-2A, -2B, and $-2 \mathrm{C}$ receptors and for agonism of $5 \mathrm{HT}-2 \mathrm{~B}$ and $-2 \mathrm{C}$ receptors. Activities were mild $\left(\mathrm{XC}_{50}>10 \mu \mathrm{M}\right)$ and comparable for all compounds, suggesting serotonergic receptor-mediated mechanisms as an unlikely factor.

Importantly, GSK1278863 and two subsequent candidates (compounds $\mathrm{E}$ and $\mathrm{F}$; human $\mathrm{CP} 4 \mathrm{H} \mathrm{IC} \mathrm{IC}_{50}>200 \mu \mathrm{M}$ ) that did not cause valvulopathy in screening 14-day rat oral toxicity studies increased hematocrits to magnitudes comparable to those induced by the four compounds that induced cardiac valve lesions (compounds A through $\mathrm{D}$ ). This suggests that polycythemia and assumed increased blood viscosity were not significant or the sole contributing factors in the valvulopathy observed in short-term studies, especially given the absence of valvular or cardiac thromboses. Thus, our experience suggests a plausible association between $\mathrm{CP} 4 \mathrm{H}$ inhibitory activity and the cardiac valve lesions observed with several nonselective HIF-prolyl-hydroxylase inhibitors in 14- or 28-day dog and/or rodent oral toxicity studies.

\section{Discussion}

Our search for novel and potent HIF prolyl hydroxylase inhibitors began using the validated principle of molecular mimicry. N-Oxalylglycine has long been used as an unreactive substrate mimetic to inhibit $\alpha$-KG-utilizing enzymes such as the prolyl 4-hydroxylases (Fig. 2) (Cunliffe et al., 1992; Mole et al., 2003; Hausinger, 2004). Extending this principle, several heteroaryl-glycinamides have been discovered as inhibitors of $\alpha$-KG-utilizing dioxygenases using a heterocyclic ring nitrogen atom to form a five-membered chelate with the enzyme-bound iron (e.g., \{[(4-hydroxy-8-iodoisoquinolin-3-yl) carbonyl]amino\}acetic acid) (McDonough et al., 2006). We postulated that an inhibitor with the potential to form a sixmembered chelate would form a strong interaction with the PHDs and result in potent inhibitors of this class of enzyme. As shown in Fig. 2, GSK1278863 (a pyrimidinetrioneglycinamide) mimics the binding of $\mathrm{N}$-oxalylglycine, chelating the catalytic iron through the glycinamide carbonyl and an acidic ring hydroxyl group in a six-membered chelate. The specific ring substitutions on the pyrimidine nucleus of GSK1278863 were derived through an extensive leadoptimization campaign and provided an inhibitor with optimized biologic profile and pharmaceutic properties for progression into clinical trials (Johnson et al., 2014; Brigandi et al., 2016; Holdstock et al., 2016; Akizawa et al., 2017); a full description of this campaign is outside the scope of the present discussion.

GSK1278863 is a novel small molecule agent that stimulates erythropoiesis through inhibition of PHDs. GSK1278863 is a potent inhibitor of all three HIF prolyl hydroxylase isozymes, PHD1, PHD2, and PHD3, with $K_{\mathrm{i}}$ apparents in the single-digit nanomolar range. Inhibition of the HIF-regulatory prolyl hydroxylases causes the accumulation of $\mathrm{HIF} \alpha$ transcription factors, resulting in increased transcription of HIF-responsive

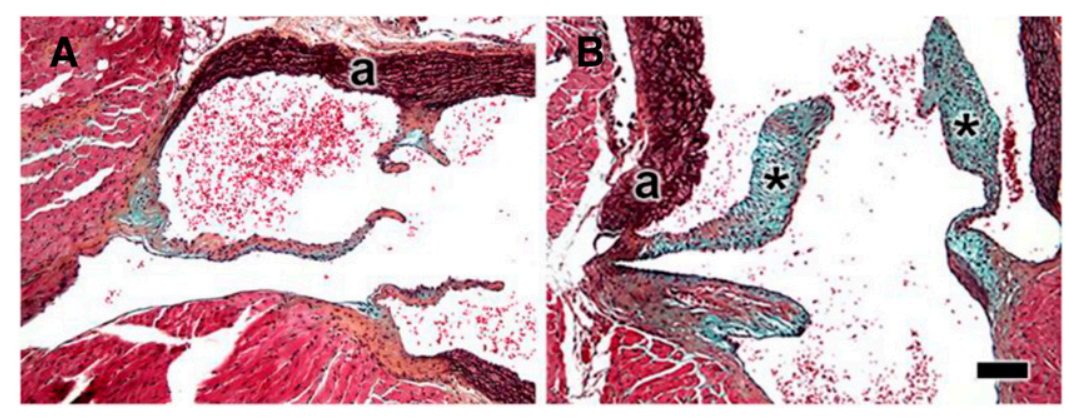

Fig. 8. Representative photomicrographs of Movat's pentachrome-stained heart sections from 28-day mouse oral toxicity study. Compound A shows myxomatous thickening (asterisks) of the aortic valve primarily due to increased proteoglycan matrix (blue staining). (A) Control mouse, (B) treated mouse; a, aortic wall. 
genes. The downstream physiologic consequences of this altered gene expression essentially simulate the body's natural adaptive response to hypoxia.

GSK1278863 is highly selective for the HIF-prolyl hydroxylases compared with related oxygen-dependent, $\alpha$-KG-utilizing metalloenzymes such as FIH and $\mathrm{CP} 4 \mathrm{H}$. GSK1278863 treatment of Hep3B cells induces downstream effects of HIF-prolyl hydroxylase inhibition, including stabilization of HIF $1 \alpha$ and HIF2 $\alpha$, and induction of EPO. A single oral dose of GSK1278863 leads to peak plasma EPO concentrations in mice within 12 hours; daily dosing of GSK1278863 in preclinical species (see Supplemental Data) leads to a robust pharmacodynamic response, resulting in a significant increase in hemoglobin and associated erythroid parameters within 7-14 days.

In toxicity studies, GSK1278863 has demonstrated an acceptable safety profile and therapeutic window, supporting clinical progression into phase 3 . Importantly, with several precandidate compounds, we observed an association between $\mathrm{CP} 4 \mathrm{H}$ inhibitory potency and development of $\mathrm{dog}$ and/or rodent cardiac valve lesions. Although further work would be required to investigate this association, it seems plausible as $\mathrm{CP} 4 \mathrm{H}$ plays a key role in collagen synthesis and triple-helix formation, which, if impaired, could impact the organization of extracellular matrix.

For example, it has been reported that interference with fibroblast/interstitial cell-mediated matrix turnover can impact the integrity and repair of cardiac valves (Jaffe et al., 1981; Glesby and Pyeritz, 1989; Gamulescu et al., 2006; Hinton et al., 2006; Hakuno et al., 2009). This is exemplified by the observation that an activin receptor-like kinase 5 (Alk5) inhibitor, a potent antifibrosis agent, causes severe and irreversible cardiac valve lesions in rats (Anderton et al., 2011). Also, Andrews et al. (2014a,b) have reported on valvulopathy related to erythropoiesis-stimulating agent in rats administered AMG-114 and several other recombinant human erythropoietins. The AMG-114-related rat valvulopathy was often accompanied by an attached thrombus. This was not the case for the four GSK PHD compounds that induced valvulopathy in short-term studies. The Andrews et al. article suggests increased hematocrit as a predisposing factor in erythropoiesis-stimulating agent-related rat toxicities, including valvulopathy. Our experiences with several PHD inhibitors that caused valvulopathy in dogs and/or rodents point to a plausible association with off-target inhibitory activity on the closely related enzyme CP4H. Importantly, GSK1278863A, the molecule in clinical trials, is $>9000$-fold selective for PHDs over $\mathrm{CP} 4 \mathrm{H}$.

$\mathrm{PHDs}$ and $\mathrm{CP} 4 \mathrm{H}$ belong to a growing enzyme superfamily of iron and $\alpha$-ketoglutarate-dependent dioxygenases. The members of this enzyme superfamily play critical roles in hypoxic signaling, DNA repair, stress response mechanisms, lipid and growth factor metabolism, and epigenetic modifications (Aravind and Koonin, 2001; Falnes et al., 2002; Chen et al., 2008; Yang et al., 2009; Aik et al., 2013; Johansson et al., 2014; Ichiyama et al., 2015). Among them, many are important targets for drug discovery and development. As most of the inhibitors of these enzymes are designed to mimic the binding of $\mathrm{N}$-oxalylglycine involving chelation of the catalytic iron and competing for $\alpha$-ketoglutarate binding (Joberty et al., 2016), our finding cautions that $\mathrm{CP} 4 \mathrm{H}$ inhibition might be an undesirable off-target activity.
In summary, we have described the preclinical development of the PHD inhibitor GSK1278863. It is a potent and selective inhibitor, demonstrating 600- to 2800 -fold selectivity against FIH and $>9000$-fold selectivity against CP4H. GSK1278863 stabilized HIF1 $\alpha$ and HIF2 $\alpha$ in Hep3B cells and led to production of EPO and subsequent increases in reticulocytes and hemoglobin in vivo. The therapeutic window provided by the demonstrated efficacy and acceptable safety margin supported the progression of GSK1278863 (daprodustat) into the clinic, where it has been evaluated in phase I (NCT00750256, NCT01319006, NCT01376232, NCT01673555, NCT02348372) and phase II (NCT01047397), and is in ongoing phase III clinical trials (NCT02876835, NCT02879305) for the treatment of anemia of chronic kidney disease.

\section{Acknowledgments}

The authors thank Erding Hu, Kendall Frazier, and Tim Hart for their assistance with study management and critical review, and Tracy Gales for image support, all of whom are employees of GlaxoSmithKline. All listed authors met the criteria for authorship set forth by the International Committee for Medical Journal Editors.

\section{Authorship Contributions}

Participated in research design: Adams, Ariazi, Duffy, EricksonMiller, Luo.

Conducted experiments: Ariazi, Biju, Pappalardi.

Contributed new reagents or analytic tools: Duffy, Fitch, Shaw, Wiggall.

Performed data analysis: Adams, Ariazi, Duffy, Hugger, Luo, Pappalardi.

Wrote or contributed to the writing of the manuscript: Adams, Ariazi, Duffy, Pappalardi.

\section{References}

Aik W, Demetriades M, Hamdan MK, Bagg EA, Yeoh KK, Lejeune C, Zhang Z, McDonough MA, and Schofield CJ (2013) Structural basis for inhibition of the fat mass and obesity associated protein (FTO). J Med Chem 56:3680-3688.

Akizawa T, Tsubakihara Y, Nangaku M, Endo Y, Nakajima H, Kohno T, Imai Y, Kawase N, Hara K, Lepore J, et al. (2017) Effects of daprodustat, a novel hypoxiainducible factor prolyl hydroxylase inhibitor on anemia management in Japanese hemodialysis subjects. Am J Nephrol 45:127-135.

Anderton MJ, Mellor HR, Bell A, Sadler C, Pass M, Powell S, Steele SJ, Roberts RR, and Heier A (2011) Induction of heart valve lesions by small-molecule ALK5 inhibitors. Toxicol Pathol 39:916-924.

Andrews DA, Boren BM, Turk JR, Boyce RW, He YD, Hamadeh HK, Mytych DT, Barger TE, Salimi-Moosavi H, Sloey B, et al. (2014a) Dose-related differences in the pharmacodynamic and toxicologic response to a novel hyperglycosylated analog of recombinant human erythropoietin in Sprague-Dawley rats with similarly high hematocrit. Toxicol Pathol 42:524-539.

Andrews DA, Pyrah IT, Boren BM, Tannehill-Gregg SH, and Lightfoot-Dunn RM (2014b) High hematocrit resulting from administration of erythropoiesisstimulating agents is not fully predictive of mortality or toxicities in preclinical species. Toxicol Pathol 42:510-523.

Appelhoff RJ, Tian YM, Raval RR, Turley H, Harris AL, Pugh CW, Ratcliffe PJ, and Gleadle JM (2004) Differential function of the prolyl hydroxylases PHD1, PHD2, and PHD3 in the regulation of hypoxia-inducible factor. $J$ Biol Chem $\mathbf{2 7 9}$ 38458-38465.

Aravind L and Koonin EV (2001) The DNA-repair protein AlkB, EGL-9, and leprecan define new families of 2-oxoglutarate- and iron-dependent dioxygenases. Genome Biol 2:research0007.1-research0007.8.

Arjamaa O and Nikinmaa M (2006) Oxygen-dependent diseases in the retina: role of hypoxia-inducible factors. Exp Eye Res 83:473-483.

Bao W, Qin P, Needle S, Erickson-Miller CL, Duffy KJ, Ariazi JL, Zhao S, Olzinski AR, Behm DJ, Pipes GC, et al. (2010) Chronic inhibition of hypoxia-inducible factor prolyl 4-hydroxylase improves ventricular performance, remodeling, and vascularity after myocardial infarction in the rat. J Cardiovasc Pharmacol 56:147-155. Berra E, Benizri E, Ginouvès A, Volmat V, Roux D, and Pouysségur J (2003) HIF prolyl-hydroxylase 2 is the key oxygen sensor setting low steady-state levels of HIF-1 $\alpha$ in normoxia. EMBO $J$ 22:4082-4090.

Bishop T and Ratcliffe PJ (2015) HIF hydroxylase pathways in cardiovascular physiology and medicine. Circ Res 117:65-79.

Brigandi RA, Johnson B, Oei C, Westerman M, Olbina G, de Zoysa J, Roger SD, Sahay M, Cross N, McMahon L, et al.; PHI112844 Investigators (2016) A novel hypoxia-inducible factor-prolyl hydroxylase inhibitor (GSK1278863) for anemia in CKD: a 28-day, phase 2A randomized trial. Am J Kidney Dis 67:861-871. 
Chai D, Colon M, Duffy KJ, Fitch DM, Tedesco R and Zimmerman M (2007) inventors, Smithkline Beecham Corporation, assignee. Prolyl hydroxylase antagonists. WIPO patent WO 2007038571 A2. 2005 Sep 26.

Chan MC, Ilott NE, Schödel J, Sims D, Tumber A, Lippl K, Mole DR, Pugh CW, Ratcliffe PJ, Ponting CP, et al. (2016) Tuning the transcriptional response to hypoxia by inhibiting hypoxia-inducible factor (HIF) prolyl and asparaginyl hydroxylases. J Biol Chem 291:20661-20673.

Chen YH, Comeaux LM, Eyles SJ, and Knapp MJ (2008) Auto-hydroxylation of FIH1: an Fe(ii), $\alpha$-ketoglutarate-dependent human hypoxia sensor. Chem Commun (Camb) (39):4768-4770.

Cheng Y and Prusoff WH (1973) Relationship between the inhibition constant $\left(K_{\mathrm{I}}\right)$ and the concentration of inhibitor which causes 50 per cent inhibition $\left(\mathrm{I}_{50}\right)$ of an enzymatic reaction. Biochem Pharmacol 22:3099-3108.

Cockman ME, Masson N, Mole DR, Jaakkola P, Chang GW, Clifford SC, Maher ER, Pugh CW, Ratcliffe PJ, and Maxwell PH (2000) Hypoxia inducible factor-alpha binding and ubiquitylation by the von Hippel-Lindau tumor suppressor protein. $J$ Biol Chem 275:25733-25741.

Connolly HM, Crary JL, McGoon MD, Hensrud DD, Edwards BS, Edwards WD, and Schaff HV (1997) Valvular heart disease associated with fenfluramine-phentermine. $N$ Engl J Med 337:581-588.

Copeland RA (2005) Evaluation of enzyme inhibitors in drug discovery. A guide for medicinal chemists and pharmacologists. Methods Biochem Anal 46:1-265.

Cunliffe CJ, Franklin TJ, Hales NJ, and Hill GB (1992) Novel inhibitors of prolyl 4-hydroxylase. 3 . Inhibition by the substrate analogue $\mathrm{N}$-oxaloglycine and its derivatives. $J$ Med Chem 35:2652-2658.

Duffy KJ, Fitch DM, Jin J, Liu R, Shaw A, N, and Wiggall KJ (2007) inventors, Smithkline Beecham Corporation, assignee. Prolyl hydroxylase inhibitors. WIPO patent WO 2007150011 A8. 2006 Jun 23.

Epstein AC, Gleadle JM, McNeill LA, Hewitson KS, O'Rourke J, Mole DR, Mukherji M, Metzen E, Wilson MI, Dhanda A, et al. (2001) C. elegans EGL-9 and mammalian homologs define a family of dioxygenases that regulate HIF by prolyl hydroxylation. Cell 107:43-54.

Falnes PO, Johansen RF, and Seeberg E (2002) AlkB-mediated oxidative demethylation reverses DNA damage in Escherichia coli. Nature 419:178-182.

Forristal CE and Levesque JP (2014) Targeting the hypoxia-sensing pathway in clinical hematology. Stem Cells Transl Med 3:135-140.

Gamulescu MA, Chen Y, He S, Spee C, Jin M, Ryan SJ, and Hinton DR (2006) Transforming growth factor $\beta 2$-induced myofibroblastic differentiation of human retinal pigment epithelial cells: regulation by extracellular matrix proteins and hepatocyte growth factor. Exp Eye Res 83:212-222.

Glesby MJ and Pyeritz RE (1989) Association of mitral valve prolapse and systemic abnormalities of connective tissue. A phenotypic continuum. JAMA 262:523-528.

Ha VT, Marshall MK, Elsas LJ, Pinnell SR, and Yeowell HN (1994) A patient with Ehlers-Danlos syndrome type VI is a compound heterozygote for mutations in the lysyl hydroxylase gene. J Clin Invest 93:1716-1721.

Hakuno D, Kimura N, Yoshioka M, and Fukuda K (2009) Molecular mechanisms underlying the onset of degenerative aortic valve disease. J Mol Med (Berl) 87:17-24.

Hausinger RP (2004) FeII/alpha-ketoglutarate-dependent hydroxylases and related enzymes. Crit Rev Biochem Mol Biol 39:21-68.

Hewitson KS, McNeill LA, Riordan MV, Tian YM, Bullock AN, Welford RW, Elkins JM, Oldham NJ, Bhattacharya S, Gleadle JM, et al. (2002) Hypoxia-inducible factor (HIF) asparagine hydroxylase is identical to factor inhibiting HIF (FIH) and is related to the cupin structural family. J Biol Chem 277:26351-26355.

Hinton RB, Jr, Lincoln J, Deutsch GH, Osinska H, Manning PB, Benson DW, and Yutzey KE (2006) Extracellular matrix remodeling and organization in developing and diseased aortic valves. Circ Res 98:1431-1438.

Hoffman EC, Reyes H, Chu FF, Sander F, Conley LH, Brooks BA, and Hankinson O (1991) Cloning of a factor required for activity of the Ah (dioxin) receptor. Science 252:954-958.

Holdstock L, Meadowcroft AM, Maier R, Johnson BM, Jones D, Rastogi A, Zeig S, Lepore JJ, and Cobitz AR (2016) Four-week studies of oral hypoxia-inducible factor-prolyl hydroxylase inhibitor GSK1278863 for treatment of anemia. J Am Soc Nephrol 27:1234-1244.

Ichiyama K, Chen T, Wang X, Yan X, Kim BS, Tanaka S, Ndiaye-Lobry D, Deng Y, Zou Y, Zheng $\mathrm{P}$, et al. (2015) The methylcytosine dioxygenase Tet2 promotes DNA demethylation and activation of cytokine gene expression in T cells. Immunity 42 613-626.

Ivan M, Kondo K, Yang H, Kim W, Valiando J, Ohh M, Salic A, Asara JM, Lane WS and Kaelin WG, Jr (2001) HIF $\alpha$ targeted for VHL-mediated destruction by proline hydroxylation: implications for $\mathrm{O}_{2}$ sensing. Science 292:464-468.

Jaakkola P, Mole DR, Tian YM, Wilson MI, Gielbert J, Gaskell SJ, von Kriegsheim A, Hebestreit HF, Mukherji M, Schofield CJ, et al. (2001) Targeting of HIF-alpha to the von Hippel-Lindau ubiquitylation complex by $\mathrm{O}_{2}$-regulated prolyl hydroxylation. Science 292:468-472.

Jaffe AS, Geltman EM, Rodey GE, and Uitto J (1981) Mitral valve prolapse: a consistent manifestation of type IV Ehlers-Danlos syndrome. The pathogenetic role of the abnormal production of type III collagen. Circulation 64 $121-125$

Joberty G, Boesche M, Brown JA, Eberhard D, Garton NS, Humphreys PG, Mathieson T, Muelbaier M, Ramsden NG, Reader V, et al. (2016) Interrogating the druggability of the 2-oxoglutarate-dependent dioxygenase target class by chemical proteomics. ACS Chem Biol 11:2002-2010.

Johansson C, Tumber A, Che K, Cain P, Nowak R, Gileadi C, and Oppermann U (2014) The roles of Jumonji-type oxygenases in human disease. Epigenomics 6:89-120.

Johnson BM, Stier BA, and Caltabiano S (2014) Effect of food and gemfibrozil on the pharmacokinetics of the novel prolyl hydroxylase inhibitor GSK1278863. Clin Pharmacol Drug Dev 3:109-117.

Kersteen EA, Higgin JJ, and Raines RT (2004) Production of human prolyl 4-hydroxylase in Escherichia coli. Protein Expr Purif 38:279-291.
Lando D, Peet DJ, Gorman JJ, Whelan DA, Whitelaw ML, and Bruick RK (2002) FIH-1 is an asparaginyl hydroxylase enzyme that regulates the transcriptional activity of hypoxia-inducible factor. Genes Dev 16:1466-1471.

Lieb ME, Menzies K, Moschella MC, Ni R, and Taubman MB (2002) Mammalian EGLN genes have distinct patterns of mRNA expression and regulation. Biochem Cell Biol 80:421-426.

Lincoln J, Lange AW, and Yutzey KE (2006) Hearts and bones: shared regulatory mechanisms in heart valve, cartilage, tendon, and bone development. Dev Biol 294:292-302. Liu Q, Davidoff O, Niss K, and Haase VH (2012) Hypoxia-inducible factor regulates hepcidin via erythropoietin-induced erythropoiesis. J Clin Invest 122:4635-4644.

Loboda A, Jozkowicz A, and Dulak J (2010) HIF-1 and HIF-2 transcription factorssimilar but not identical. $\mathrm{Mol}$ Cells 29:435-442.

Loboda A, Jozkowicz A, and Dulak J (2012) HIF-1 versus HIF-2-is one more important than the other? Vascul Pharmacol 56:245-251.

Mahon PC, Hirota K, and Semenza GL (2001) FIH-1: a novel protein that interacts with HIF- $1 \alpha$ and VHL to mediate repression of HIF-1 transcriptional activity. Genes Dev 15:2675-2686.

Makino Y, Cao R, Svensson K, Bertilsson G, Asman M, Tanaka H, Cao Y, Berkenstam A, and Poellinger L (2001) Inhibitory PAS domain protein is a negative regulator of hypoxia-inducible gene expression. Nature 414:550-554

Mathieu JR, Heinis M, Zumerle S, Delga S, Le Bon A, and Peyssonnaux C (2014) Investigating the real role of HIF-1 and HIF-2 in iron recycling by macrophages. Haematologica 99:e112-e114.

Maxwell PH, Wiesener MS, Chang GW, Clifford SC, Vaux EC, Cockman ME, Wykoff CC, Pugh CW, Maher ER, and Ratcliffe PJ (1999) The tumour suppressor protein VHL targets hypoxia-inducible factors for oxygen-dependent proteolysis. Nature 399:271-275.

McDonough MA, Li V, Flashman E, Chowdhury R, Mohr C, Liénard BM, Zondlo J, Oldham NJ, Clifton IJ, Lewis J, et al. (2006) Cellular oxygen sensing: crystal structure of hypoxia-inducible factor prolyl hydroxylase (PHD2). Proc Natl Acad Sci USA 103:9814-9819.

Minamishima YA, Moslehi J, Bardeesy N, Cullen D, Bronson RT, and Kaelin WG, Jr (2008) Somatic inactivation of the PHD2 prolyl hydroxylase causes polycythemia and congestive heart failure. Blood 111:3236-3244.

Mole DR, Schlemminger I, McNeill LA, Hewitson KS, Pugh CW, Ratcliffe PJ, and Schofield CJ (2003) 2-Oxoglutarate analogue inhibitors of HIF prolyl hydroxylase. Bioorg Med Chem Lett 13:2677-2680.

Myllyharju J and Kivirikko KI (2001) Collagens and collagen-related diseases. Ann Med 33:7-21.

Pappalardi MB, Martin JD, Jiang Y, Burns MC, Zhao H, Ho T, Sweitzer S, Lor L, Schwartz B, Duffy K, et al. (2008) Biochemical characterization of human prolyl hydroxylase domain protein 2 variants associated with erythrocytosis. Biochemistry 47:11165-11167.

Pappalardi MB, McNulty DE, Martin JD, Fisher KE, Jiang Y, Burns MC, Zhao H, Ho T, Sweitzer S, Schwartz B, et al. (2011) Biochemical characterization of human HIF hydroxylases using HIF protein substrates that contain all three hydroxylation sites. Biochem J 436:363-369.

Percy MJ, Zhao Q, Flores A, Harrison C, Lappin TR, Maxwell PH, McMullin MF, and Lee FS (2006) A family with erythrocytosis establishes a role for prolyl hydroxylase domain protein 2 in oxygen homeostasis. Proc Natl Acad Sci USA 103: 654-659.

Philipp S, Jürgensen JS, Fielitz J, Bernhardt WM, Weidemann A, Schiche A, Pilz B, Dietz R, Regitz-Zagrosek V, Eckardt KU, et al. (2006) Stabilization of hypoxia inducible factor rather than modulation of collagen metabolism improves cardiac function after acute myocardial infarction in rats. Eur $J$ Heart Fail 8 347-354

Pugh CW, Tan CC, Jones RW, and Ratcliffe PJ (1991) Functional analysis of an oxygen-regulated transcriptional enhancer lying $3^{\prime}$ to the mouse erythropoietin gene. Proc Natl Acad Sci USA 88:10553-10557.

Ratcliffe PJ (2007) HIF-1 and HIF-2: working alone or together in hypoxia? J Clin Invest 117:862-865.

Schödel J, Oikonomopoulos S, Ragoussis J, Pugh CW, Ratcliffe PJ, and Mole DR (2011) High-resolution genome-wide mapping of HIF-binding sites by ChIP-seq. Blood 117:e207-e217.

Semenza GL (2012) Hypoxia-inducible factors in physiology and medicine. Cell 148: 399-408.

Semenza GL, Agani F, Feldser D, Iyer N, Kotch L, Laughner E, and Yu A (2000) Hypoxia, HIF-1, and the pathophysiology of common human diseases. Adv Exp Med Biol 475:123-130.

Semenza GL, Nejfelt MK, Chi SM, and Antonarakis SE (1991) Hypoxia-inducible nuclear factors bind to an enhancer element located 3 ' to the human erythropoietin gene. Proc Natl Acad Sci USA 88:5680-5684.

Semenza GL and Wang GL (1992) A nuclear factor induced by hypoxia via de novo protein synthesis binds to the human erythropoietin gene enhancer at a site required for transcriptional activation. Mol Cell Biol 12:5447-5454.

Shaw AN, Duffy KJ, Miller WH, Myers AK and Zimmerman M (2008) inventors, Smithkline Beecham Corporation, assignee. N-substituted glycine derivatives: prolyl hydroxylase inhibitors. WIPO patent WO2008089052 A2 2007 Jan 12

Sinclair AM (2013) Erythropoiesis stimulating agents: approaches to modulate activity. Biologics 7:161-174

Takeda K, Aguila HL, Parikh NS, Li X, Lamothe K, Duan LJ, Takeda H, Lee FS, and Fong GH (2008) Regulation of adult erythropoiesis by prolyl hydroxylase domain proteins. Blood 111:3229-3235.

Tian H, McKnight SL, and Russell DW (1997) Endothelial PAS domain protein 1 (EPAS1), a transcription factor selectively expressed in endothelial cells. Genes Dev 11:72-82.

Wang GL, Jiang BH, Rue EA, and Semenza GL (1995) Hypoxia-inducible factor 1 is a basic-helix-loop-helix-PAS heterodimer regulated by cellular $\mathrm{O}_{2}$ tension. Proc Natl Acad Sci USA 92:5510-5514. 
Wei H, Bedja D, Koitabashi N, Xing D, Chen J, Fox-Talbot K, Rouf R, Chen S, Steenbergen C, Harmon JW, et al. (2012) Endothelial expression of hypoxiainducible factor 1 protects the murine heart and aorta from pressure overload by suppression of TGF- $\beta$ signaling. Proc Natl Acad Sci USA 109:E841-E850.

Whyte MK and Walmsley SR (2014) The regulation of pulmonary inflammation by the hypoxia-inducible factor-hydroxylase oxygen-sensing pathway. Ann Am Thorac Soc 11 (Suppl 5):S271-S276.

Yang J, Ledaki I, Turley H, Gatter KC, Montero JC, Li JL, and Harris AL (2009) Role of hypoxia-inducible factors in epigenetic regulation via histone demethylases. Ann N Y Acad Sci 1177:185-197.
Yoon D, Pastore YD, Divoky V, Liu E, Mlodnicka AE, Rainey K, Ponka P, Semenza GL, Schumacher A, and Prchal JT (2006) Hypoxia-inducible factor-1 deficiency results in dysregulated erythropoiesis signaling and iron homeostasis in mouse development. J Biol Chem 281:25703-25711.

Address correspondence to: Dr. Jennifer L Ariazi, GlaxoSmithKline, 709 Swedeland Road UW2230, King of Prussia, PA 19406. E-mail: jennifer.l. ariazi@gsk.com 